\title{
The Climate for Entrepreneurship at Higher Education Institutions
}

\author{
Heiko Bergmann $^{\mathrm{a}}$ *, Mario Geissler ${ }^{\mathrm{b}}$, Christian Hundt $^{\mathrm{c}}$, Barbara Grave $^{\mathrm{d}}$ \\ Dufourstrasse 40a, 9000 St.Gallen, Switzerland \\ Tel.: +41712247100 \\ Email: heiko.bergmann@unisg.ch \\ ${ }^{\mathrm{b}}$ Chemnitz University of Technology \\ Dittesstraße 15, 09126 Chemnitz, Germany \\ Tel: +4937153136685 \\ Email: mario.geissler@wirtschaft.tu-chemnitz.de
}

${ }^{\text {a }}$ University of St.Gallen, Swiss Research Institute of Small Business and Entrepreneurship

${ }^{\mathrm{c}}$ Ruhr University Bochum, Geography Department, Urban and Regional Economics, Universitätsstraße 150, 44780, Bochum, Germany \& Johann Heinrich von Thünen Institute, Institute of Rural Studies, Bundesallee 64, 38116 Braunschweig, Germany

Tel: +495315965510.

Email: christian.hundt@thuenen.de

${ }^{\text {d }}$ SV Wissenschaftsstatistik GmbH, Baedekerstraße 1, 45128 Essen, Germany

Tel: +492018401424

Email: barbara.grave@stifterverband.de

* corresponding author

This paper has been accepted for publication in Research Policy. The final publication is available at https://doi.org/10.1016/j.respol.2018.01.018 


\title{
The Climate for Entrepreneurship at Higher Education Institutions
}

\begin{abstract}
While the importance of a supportive context for entrepreneurship is widely acknowledged, its antecedents are rarely investigated. We apply the concept of organizational climate to higher education institutions and examine the drivers of students' perceptions of the entrepreneurial climate in their university. Combining data from two unique datasets and using multilevel techniques, we analyze the relationship between university characteristics and such climate perceptions of 8009 students at public universities in Germany. We find university entrepreneurship measures to have a positive effect on students' climate perceptions, which also depend on students' background and gender. In addition, we find evidence for different peer effects, depending on students' affinity for entrepreneurship. For the general student population, including entrepreneurship content in their normal studies seems to be required to initiate a social process of sensemaking. However, students' perception of the entrepreneurial climate only depend to a certain degree on intentional entrepreneurship measures. In our study, general university characteristics have the strongest influence on climate perceptions. Overall, our study adds to our understanding of which parameters are important for establishing a more favorable and inspiring climate for becoming an entrepreneur at higher education institutions.
\end{abstract}

Keywords: Entrepreneurial climate; Students; Public Universities; University support measures; Peer effects; Germany

JEL codes: L260; I210, I230, J240, O380

\section{Introduction}

There is growing evidence that the social and organizational context at universities has a substantial impact on the entrepreneurial attitudes and activities of academics and students (Bercovitz and Feldman, 2008; Hunter et al., 2011; Kenney and Goe, 2004; Walter et al., 2013). Related to this stream of literature, the concept of entrepreneurial climate has gained attention in the academic literature and public debate, capturing the perceptions of the members of an organization to what degree entrepreneurial activities are supported in the respective context (European Commission and OECD, 2012; Geissler et al., 2010; Kauffman Foundation, 2008; U.S. Department of Commerce, 2013). More and more universities have 
implemented measures to improve their entrepreneurial climate with the aim of fostering the entrepreneurial propensity of students and researchers (Eickelpasch and Fritsch, 2005; Rasmussen and Borch, 2010). Estimates suggest that, for example, universities in Germany spend more than 75 million Euro per year on entrepreneurship support measures (Frank et al., 2017). In the beginning, the focus of these endeavors was on the creation of an entrepreneurial climate (or culture) among academics with the intention to encourage technology transfer and the creation of spin-off companies (Etzkowitz et al., 2000). However, increasingly these measures also focus on students (Mok, 2005; Siegel and Wright, 2015). For example, one of the key objectives of EXIST, a large support program of the German Federal Ministry for Economic Affairs and Energy (BMWi), is to "establish a culture of entrepreneurship in university teaching, research and management" and promote a "favourable climate"1 among students, graduates and academics (Kulicke, 2014, p. 1f). One reason for this change in emphasis might be that startups by recent university graduates have been found to be much more frequent than spin-offs by their faculty and also not of low quality (Åstebro et al., 2012). Presumably, the most prominent measure in this respect is the establishment of Chairs of entrepreneurship, which typically offer relevant courses and entrepreneurship-related services for students. In Europe and in the U.S. there has been an enormous expansion of respective curricula and programs (Kuratko, 2005; Schmude et al., 2008). Universities also offer entrepreneurship advice, organize business plan competitions and provide relevant facilities (Kauffman Foundation, 2008). Yet, despite these growing efforts, there is hardly any systematic research on whether these measures have any impact on the perceived climate for entrepreneurship among students. Given these efforts and the potentially high number of start-ups by students and recent graduates, we need to better understand the nature and the drivers of

\footnotetext{
${ }^{1}$ Frequently in such policy reports, the terms culture and climate are used interchangeably.
} 
such perceptions. Geissler, Jahn, \& Haefner (2010) provide some evidence on individual climate perceptions for a limited number of organizations, without, however, being able to analyze the effect of contextual characteristics. Similarly, the growing literature on entrepreneurship education only looks at individual-level effects without considering the potential broader impact of such courses or programs on the organizational climate (Martin et al., 2013; Pittaway and Cope, 2007).

It is against this background that this paper aims to contribute to our understanding of the drivers of students' perceptions of the entrepreneurial climate in their university. Just like climate in general, entrepreneurial climate can be conceptualized in two different ways. Individual climate perceptions constitute the so-called psychological climate. If these individual perceptions match to a certain degree among organizational members, they can subsequently be aggregated to the unit-level and are usually referred to as organizational climate. Organizational climate measures shared perceptions and is thus not an individual phenomenon but a group-level construct, i.e. a property of organizations or their sub-units (Glick, 1985). Because we are interested in the underlying factors of a positive entrepreneurial climate, we focus on individual psychological climate perceptions, which are also the building block of broader climate conceptualizations. Specifically, we analyze the entrepreneurial climate perceptions among the general student body of public universities and study the impact of commonly applied policy measures to foster such a climate. While studies on start-ups by researchers and faculty members typically investigate the effect of technology transfer offices and intellectual property regimes (Djokovic and Souitaris, 2008), we focus on the effect of measures that are specifically targeted at students, like the existence of specialized support and advice institutions, entrepreneurship education, and the available financial budget for such measures. We conceptualize entrepreneurial climate as individuals' perceptions to what degree entrepreneurial behavior is encouraged, rewarded and supported in the university setting. We use and combine data from two unique datasets: Based on survey data, we measure 
the perceptions of the entrepreneurial climate of 8009 students of different subjects at 22 public universities in Germany. The organizational characteristics are taken from a comprehensive study on entrepreneurship support measures at universities in Germany.

Our analyses suggests that individual and contextual characteristics influence students' climate perceptions. Importantly, the effect of some context characteristics depends on personal characteristics of the students. We also find evidence for different social effects of peers. For the general student population, universities can improve climate perceptions by sensitizing and instructing a broad spectrum of students - including previously uninterested ones - for entrepreneurship. Our results suggest that this can initiate a discussion among previously uninterested students and affect those that have not themselves participated in an entrepreneurship course. For students with a previous affinity for entrepreneurship, elective offerings seem more appropriate to foster climate perceptions. Our analyses also suggest that universities' general characteristics like size (negatively) and general reputation (positively) influence climate perceptions to a large extent. The impact of these characteristics is bigger than that of intentional entrepreneurship measures. Thus, universities might develop a reasonably positive entrepreneurial climate without explicit policy measures to foster it. Overall, our results improve our understanding of the entrepreneurial climate at universities and contribute to the general literature on organizational climate and its antecedents.

\section{Research on psychological and organization climate and related concepts}

Research regarding the impact of organizations on their members has a long history in organizational science (Glick, 1985; Payne and Pugh, 1976; Weick, 1995). Originating from Lewin's (1936) classic observation that human behavior is a function of the person and his or her environment, a broad stream of literature has analyzed the role of the social context in organizations, typically applying the concepts of organizational climate or organizational culture (Schein, 1990; Schneider et al., 2017). 
Organizational climate research is concerned with how members of an organization perceive and interpret their environment. Two different climate conceptualizations can be distinguished, psychological climate and organizational climate (Glick, 1985) (for extensive literature reviews concerning psych./org. climate: see James et al., 2008; Kuenzi and Schminke, 2009; Schneider et al., 2013). At an individual level, people's perceptions of their environment constitute the psychological climate, which is a product of the individual's cognitive construction of a certain situation. Such individual climate perceptions derive from the observation of and experience with organizational characteristics and events, like for example policies, practices and procedures (Schneider et al., 2017). As such, psychological climate is not only dependent on organizational aspects but also involves an interaction of environmental and individual characteristics. Psychological climate perceptions can differ between individuals who are more or less attentive to certain organizational characteristics or who process perceived environmental stimuli differently (James et al., 1978). Despite forming individual perceptions, organizational members are likely to develop similar (but not necessarily identical) climate perceptions because they are confronted with the same environment and because they interact. In this case, perceptions are partly shared and can be aggregated to the level of groups, departments, or whole organization; they are then typically referred to as organizational climate (Patterson et al., 2005). Organizational climate has been described as peoples' shared perceptions of organizational characteristics, such as "practices, procedures, and kinds of behavior that get rewarded and supported in a particular setting" (Schneider, 1990: 384). Because of its shared nature, organizational climate is an attribute of organizations or subunits thereof rather than of individuals.

Within an organization, different dimensions or sub-dimensions of a generalized climate can exist. Schneider \& Reichers (1983) argue that the concept of climate needs to have a specific reference; otherwise, it is meaningless. Therefore, research usually analyzes specific organizational climates, e.g. climate for service (Wu et al., 2008), justice (Walumbwa et al., 
2008), innovation (Lee et al., 2011), or safety (Wu et al., 2007; Zohar and Luria, 2005). Differences in the characteristics of the work environment among organizational units can lead to different climate manifestations within the same organization. In such a case, the climate at work units or departments rather than the whole organization is the appropriate level of analysis (Zohar and Luria, 2005).

Studying psychological and organizational climate is important for our understanding of motivational and behavioral outcomes at the individual as well as the organizational level, for example concerning organizational performance (Riordan et al., 2005), satisfaction (Lee et al., 2011), quality perception (Schneider et al., 1998), and entrepreneurial intentions (Huyghe and Knockaert, 2015). While the concepts of psychological and organizational climate are typically applied to employees in firms, they have also been used to study students at schools or universities (Ancis et al., 2000; Anderson, 1982; Cureton, 2003; Lüdtke et al., 2006; Pfeifer and Schneider, 1974; Thapa et al., 2013).

Organizational culture is the second important concept which is frequently used to study and explain the organization's impact on its members (Schneider et al., 2017). Climate and culture possess a conceptual and definitional overlap since both relate to individuals' experience of their organization and are, thus, sometimes used interchangeably (Patterson et al., 2005). However, while organizational climate refers to the way how individuals experience and interpret their organizational setting, research on organizational culture tries to understand people's underlying assumptions and values of why they behave the way they do (Schein, 1990). Culture refers to the organizations' deep-rooted structure that is best understood as patterns of basic assumptions and values. It exists at a fundamental and sometimes preconscious level of awareness (Schneider et al., 2017). Culture evolves over time and for a culture to form, there needs to be enough stability and common history to have allowed a culture to form (Schein, 1990). Respective studies frequently focus on the historical evolution of organizations and their social environment and are well suited to gain an in-depth understanding of 
social context and its development on a case-by-case basis. For example, studies have investigated the impact of university culture on faculty entrepreneurial activity, usually using a multiple case-study approach (Bercovitz and Feldman, 2008; Kenney and Goe, 2004). However, concerning students, the concept appears less suitable because of their frequent turnover at universities, which makes it unlikely that an overarching culture among students has emerged.

As we are interested in how students perceive their university context and to what degree universities' measures to foster entrepreneurship have an effect, a climate perspective is especially appropriate for our research purposes (Denison, 1996). We analyze individual climate perceptions because they are also the building block of organizational climate. After having analyzed the individual perceptions, we also examine whether it is possible to speak about an organizational climate for entrepreneurship at the aggregate level.

To conclude, climate can be interpreted as a surface manifestation of culture (Schein, 2000). This is associated with a loss in analytical depth but with the possibility to assess the impact of contextual factors by comparing different organizations. We define entrepreneurial climate as students' individual perceptions of university characteristics associated with entrepreneurial activities such as seeking for entrepreneurial opportunities, developing new business ideas, starting a new venture or other kinds of entrepreneurial behaviors that are rewarded and supported at the respective university.

\section{The drivers of positive climate perceptions}

Individual climate perceptions (i.e. psychological climate) are a product of the individual's cognitive construction of his or her environment. While policies, practices, and procedures are considered as objective and lasting properties of an organization, the literature on psychological climate tries to understand how people perceive, interpret and attach meaning to these properties. Members of an organization perceive and make sense of organizational policies, practices, and procedures in psychologically meaningful terms (Rentsch, 1990, p. 668). These 
interpretations enable an individual to understand events and act accordingly. Different psychological processes such as perceptual or cognitive filtering or interpretation are involved in the creation of a psychological climate. Thus, psychological climate is not only dependent on organizational events but also involves an interaction of these events with individual characteristics (James et al., 1978). Psychological climate perceptions are at least partly dependent on peoples' knowledge and personal value system (James and Sells, 1981). Personal values describe what a person wants or seeks to obtain and such values produce the schemas that are used to evaluate and appraise organizational attributes (James et al., 2008). Peoples' individual socialization and family background affect such values and are, hence, relevant for climate perceptions. Psychological climate is a property of the individual and, therefore, the individual is the appropriate level of theory, measurement, and analysis (Parker et al., 2003).

While psychological climate is an individual-level construct, individual climate perceptions are still likely to be similar to some extent among the member of an organization. Schneider \& Reichers (1983) describe three different, not mutually exclusive mechanisms of how such a 'shared' understanding might evolve among organizational members. These mechanisms put different emphasis on how organizational members are selected and how they develop perceptions of their context. First, people might perceive and interpret the rules and procedures in an organization similarly, irrespective of their personal characteristics. Because organizational members are being confronted with the same organizational rules and procedures they develop similar climate perceptions (Payne and Pugh, 1976). The second mechanisms acknowledges that peoples' individual characteristics influence climate perceptions. However, organizational selection and retention measures produce a relatively homogenous membership in an organization, which lead to similar climate perceptions. The third mechanism, the symbolic interactionist view, is arguably the predominant view of organizational climate formation. While this approach acknowledges the importance of structural char- 
acteristics of the organization for developing similar climate perceptions, it argues that meaning is not given but evolves from peoples' interaction (Schneider and Reichers, 1983). People communicate and interact with each other to understand their environment and, by doing so, develop a similar understanding of organizational practices; a process that has also been termed collective or social sense-making (Ashforth, 1985). This interaction leads to converging but not necessarily uniform perceptions. While the symbolic interactionist view takes a process perspective and stresses the importance of the interaction among organizational members, the first two mechanisms described do not require any interaction.

Social sensemaking processes do not evolve uncontrolled but can be governed and influenced. Research points to the importance of leader behavior for climate formation. Leaders use power, coordination techniques and motivation tools to influence subordinates in order to achieve organizational goals (Borucki and Burke, 1999). When leaders try to influence others' understanding of an issue, they can be said to engage in 'sensegiving' (Gioia and Chittipeddi, 1991). Maitlis (2005) argues that these sensegiving attempts can be more or less controlled, i.e. they can take place in an organized form, where leaders draw on their formal authority to achieve the attendance of organizational members, or in a more informal, self-organizing form where attendance is not controlled. Controlled sensegiving processes are more likely to lead to single, dominant interpretation of an issue, i.e. a 'unitary account', whereas uncontrolled ones lead to individualistic accounts (Maitlis, 2005). Sensegiving appears especially important to integrate newcomers into the organization so that they understand the organization and what is expected of them (Ashforth, 1985).

Similar to the concept of entrepreneurial orientation in firms (Lumpkin and Dess, 1996), universities might also have an entrepreneurial orientation and introduce measures to foster entrepreneurial thinking and acting among students, which might contribute to a positive entrepreneurial climate. Previous research has studied entrepreneurial orientation in the university 
context, without, however, being able to measure it directly (O'Shea et al., 2005). Entrepreneurial orientation can be considered as an antecedent of a positive entrepreneurial climate that is mediated through effective organizational mechanisms developed to foster entrepreneurship (Van Looy et al., 2011).

Based on these general considerations, we now turn to the development of specific hypotheses concerning the factors influencing climate perceptions. Our hypothesis refer to characteristics of universities and study requirements that are likely to affect such perceptions of students.

\subsection{Financial resources}

Financial resources are necessary for universities to implement organizational measures and to fund structural characteristics of an organization (O'Shea et al., 2005). Having obtained and allocated substantial funds for the support of entrepreneurial activities can be considered a strong indicator for the existence of an entrepreneurial orientation on the institutional level (Van Looy et al., 2011). Concerning entrepreneurship, relevant support and teaching activities need appropriate financing to be viable. For example in Germany, the entrepreneurship support measures of a number of universities were enabled by financial support from the federal government. Universities had to develop concepts of how they want to support entrepreneurship and only the best concepts were funded (Kulicke, 2014). The allocation of scarce resources to entrepreneurship measures can be considered as a signal for university members that fostering entrepreneurship is an important part of the university's mission and that the university supports entrepreneurial activities. Research indicates that perceptions of this kind can foster climate formation (DeJoy, et al., 2004; Geissler et al., 2010). While students are unlikely to observe the amount of entrepreneurship spending, the availability of more resources relative to the overall budget of the university will increase the likelihood of spending on observable support measures. Given their scarce resources, public universities can be assumed to 
have difficulties in implementing suitable entrepreneurship measures in the absence of financial resources. Thus, our basic hypothesis is that more resources relative to the overall budget of the university will be helpful in fostering entrepreneurship related activities, leading to a positive entrepreneurial climate.

Hypothesis 1: The share of the university budget for the support of entrepreneurship-related activities is positively related to students' perceptions of the entrepreneurial climate in their university.

\subsection{Institutionalization of entrepreneurship}

Stable and lasting organizational characteristics are the basis on which people form perceptions about their organizational environment. The exposure to such observable institutions and symbols can influence climate perceptions (Geissler et al., 2010). For example, prior research finds that organizational factors such as the existence of a safety manager or a safety committee influence individual climate perceptions (Wu et al., 2007). Similarly, we argue that the degree to which entrepreneurship support is institutionalized at universities is positively related to the entrepreneurial climate among students. One institutional element within the university that is likely to have a strong signaling effect to students is the existence of a Chair of entrepreneurship (Rasmussen and Borch, 2010). Typically, these chairs are active in raising the awareness for entrepreneurship by offering relevant courses and providing advice for students (Klandt, 2004; Schmude et al., 2008). Another example of the institutionalization of entrepreneurship are faculty entrepreneurship officers, who also provide advice and coordinate different offerings (Walter et al., 2013). Business plan competitions (or, more generally, entrepreneurship competitions) are usually very visible and might increase the awareness of the possibility of an entrepreneurial career among academics and students (Fini et al., 2011). Overall, our hypothesis is as follows. 
Hypothesis 2a: The degree of institutionalization of entrepreneurship at universities, i.e. the existence of a Chair of entrepreneurship, faculty entrepreneurship officers or entrepreneurship competitions, is positively related to students' perceptions of the entrepreneurial climate in their university.

\subsection{Moderating effect of entrepreneur parents}

As argued above, peoples' knowledge and values influence the individual interpretation of organizational characteristics and, thus, climate perceptions (James et al., 1978). Specifically, we argue that parental self-employment will moderate the relationship between the institutionalization of entrepreneurship and entrepreneurial climate perception. The reason behind this is that entrepreneurial parents can act as a vivid source of entrepreneurship knowledge and socialization (Laspita et al., 2012). By observing and interacting with their self-employed parents, people benefit from the intergenerational transfer of business and industry knowledge and also get a basis understanding of the opportunities and challenges of an entrepreneurial career (Eesley and Wang, 2017). Additionally, as explained by social learning theory, parent entrepreneurs may act as role models for their children (Scherer et al., 1989). Overall, students with entrepreneur parents are likely to have a better understanding of the opportunities and challenges of being an entrepreneur and to have a stronger preference for an entrepreneurial career. Thus, they might see a stronger value in institutionalized entrepreneurship support at their university, leading to the following hypothesis:

Hypothesis $2 \boldsymbol{b}$ : The positive relationship between the degree of institutionalization and students' perceptions of the entrepreneurial climate is stronger for students with self-employed parents.

\subsection{Entrepreneurship courses}


While Chairs of entrepreneurship usually teach entrepreneurship, such courses are frequently also offered by academics of related subjects. ${ }^{2}$ The availability and utilization of entrepreneurship courses is likely to be important for positive entrepreneurial climate perceptions in two different respects. First, the individual participation in an entrepreneurship course should have a positive effect on climate perceptions. Students who have participated in an entrepreneurship course are likely to feel encouraged to engage in entrepreneurial activities and think about ideas for new businesses. While the participation in an entrepreneurship course might have a negative effect on entrepreneurial intentions of some individuals (von Graevenitz et al., 2010), it still raises the awareness of the importance of this topic and the perception that the university fosters entrepreneurial thinking and activity, thereby creating a positive entrepreneurial climate. Because this direct effect seems well established, we do not formulate a hypothesis about it but only include the individual course participation as control in our models.

Secondly, due to the importance of social networks and the interaction among organizational members for climate perceptions (Zagenczyk and Purvis, 2015), students might be more likely to perceive their university as supportive of entrepreneurial activities when their fellow students have taken a respective course. A high number of participants in entrepreneurship courses provides a signal to students that the university fosters and encourages learning about entrepreneurship and that becoming entrepreneurial is a desired role behavior, contributing to a positive climate. There is some empirical support for this conjecture. Geissler et al. (2010) find for students at three German universities that the perception of the existence and quality of entrepreneurship qualification programs is the most important factor influencing individual climate evaluations. In line with the symbolic interactionist view, outlined above,

\footnotetext{
${ }^{2}$ In Germany, university professors enjoy freedom in teaching and research which is even guaranteed by the constitution (Muller-Camen and Salzgeber, 2005). Thus - to a substantial degree - professors can decide themselves what courses they want to offer and what content they deem important to teach. As entrepreneurship is an important topic with growing popularity, professors of general business administration, innovation management or other subject frequently also offer entrepreneurship courses or include entrepreneurship content in their lectures. Thus, we distinguish between the institutionalization of entrepreneurship in the form of a Chair and the prevalence and use of entrepreneurship courses.
} 
students might perceive the university support of entrepreneurial thinking and acting in a similar way, even if only some of them have participated in a course (Schneider and Reichers, 1983).

We can distinguish two broad types of entrepreneurship courses: compulsory courses that are integral part of the respective curriculum in certain degree courses and elective courses, where the decision to participate is left to the students. We argue that both types of courses are likely to have a positive, albeit different effect on the entrepreneurial climate. Elective courses are likely to attract like-minded students who are interested in entrepreneurship, anyhow (von Graevenitz et al., 2010). Students self-select into these courses, presumably, in order to qualify themselves for an entrepreneurial career.

Compulsory courses target a specific group of students irrespective of their entrepreneurial attitudes or intentions. Thus, university officials and professors decide and control which groups of students have to attend such a class. Individuals have a selective perception and tend to neglect information that does not seem important to them (DeWitt and Simon, 1958). Thus, students without an interest in entrepreneurship might only become aware of and appreciate entrepreneurship support when respective topics and content are included in courses that are an integral part of their study. However, there might also be a contrary influence because compulsory courses could be perceived as patronizing rather than as supportive which would imply a deterioration of climate perceptions.

While the distinction between elective and compulsory courses might seem secondary, it does have important implications for universities aiming at improving their entrepreneurial climate. Overall, we assume that the participation of fellow students in both types of courses has a positive impact on climate perceptions.

Hypotheses 3a: While controlling for individual course participation, the share of fellow students who have attended a compulsory entrepreneurship-related course is positively related to students' perceptions of the entrepreneurial climate in their university. 
Hypotheses $3 \boldsymbol{b}$ : While controlling for individual course participation, the share of fellow students who have attended an elective entrepreneurship-related course is positively related to students' perceptions of the entrepreneurial climate in their university.

\subsection{Gender-differences in the perception of the university context}

There is clear empirical evidence that entrepreneurship is a career choice that is male-dominated (Ahl, 2006). In Europe, women are only half as likely to engage in entrepreneurial activities as men (Herrington and Kew, 2017). These differences can be traced back to different gender roles and stereotypes that are reflected in predominantly feminine and masculine career choices. Those stereotypes are also prescriptive and inform individuals about what society expects from them (Heilman, 2001). Since entrepreneurship is traditionally a dominantly male career choice (Ahl, 2006), society associates more male characteristics than female characteristics with this career. For example, research shows that entrepreneurs are often seen as bold risk takers or are described as aggressive which are traits typically associated with men (Baughn et al., 2006; Gupta et al., 2009; Mirchandani, 1999). In addition, men can be expected to interact more with men, especially, if they have an affinity for entrepreneurship as a male dominated career choice. Research on founding teams has found that men's business networks are male dominated, contributing to gender homogeneity in founding teams (Ruef et al., 2003). Based on these observations, it can be assumed that men are more likely to be positively affected by fellow students who have participated in an entrepreneurship course.

Hypothesis 3c: The positive relationship between the share of fellow students who have attended an entrepreneurship related course and students' perceptions of the entrepreneurial climate is stronger for male students.

\subsection{Individual and Organizational controls}


Because of theoretical reasons, we also considered a number of context and individual-level controls. First, due to their orientation towards practical application, universities of applied sciences are likely to be perceived as more supportive concerning entrepreneurship than traditional research universities (Bergmann et al., 2016). Second, there is strong reason to believe that the size of the university influences climate perceptions. In a firm context, prior research finds more positive climate perceptions in small compared to large organizations (Neubaum et al., 2004). Also, smaller groups are more likely to develop unitary climate perceptions in comparison to larger ones (Dawson et al., 2008). We control for the general reputation of the universities in our sample because different types of climate perceptions are likely to be positively related within an organization (DeJoy et al., 2004). Thus, a positive entrepreneurial climate is more likely to evolve at universities where people generally feel supported and promoted. We include regional population density as control because urban areas are more likely to offer the diversity which encourages and inspires entrepreneurial activity (Beaudry and Schiffauerova, 2009).

On the individual level, we control for the participation in a compulsory and for the participation in an elective entrepreneurship course, as discussed above (von Graevenitz et al., 2010). We also control for the level of study and peoples' reason for studying at their specific university. Lastly, the entrepreneurial climate is likely to differ among subjects of study because academic disciplines provide students in different ways with the knowledge, skills, and motivation to start a business (Becher, 1994).

\section{Data and Methods}

\subsection{Data}

In the empirical part of our paper, we combine data from two main sources. First, we use primary data from the 2013 Global University Entrepreneurial Spirit Students' Survey (GUESSS) 
(In the following: "student survey"). GUESSS is an international research project that investigates and compares entrepreneurial attitudes and activities of students in 34 countries in the world. Similar to other research in this area (Abreu and Grinevich, 2013), data are gathered by means of an online survey which can be considered a suitable method to reach students at different universities (Dillman et al., 2009, p.44). Previous research based on GUESSS data has e.g. looked at career choice intentions of students (Sieger and Monsen, 2015; Zellweger et al., 2011) or the formation of opportunity beliefs (Bergmann, 2017). We use GUESSS data from German universities because we match it with comprehensive data on organizational characteristics - outlined below - which is only available for Germany.

In order to avoid a sample selection bias, we only include those universities in the analysis where a simple random sample could be accomplished, i.e. where all students could be contacted by email (see Appendix A for detailed information on the GUESSS data collection and the representativeness of the data). Also, we only include public universities because this type of university is typical for the German and European university landscape (Daraio et al., 2011). ${ }^{3}$ Overall, there are 22 universities in our sample (15 universities of applied sciences and 7 traditional research universities). The share of students at universities of applied sciences is slightly higher in our sample than overall at public universities in Germany $(68 \%$ compared to $62 \%)$.

Students are more likely to interact with students studying the same or a related subject at their university. Therefore, we calculate the variables on peer-group effects (i.e. shares of students with entrepreneurship course attendance) for subject groups at universities, as explained below. This has also implications for our data set because we can only include cases where at least ten students from one subject group at one university provided data to be able

\footnotetext{
${ }^{3}$ In 2014 , only $7 \%$ of all students in Germany studied at private universities. One reason for the dominance of public universities is that they are largely state-financed and hardly charge any tuition fees.
} 
to calculate reliable mean values on entrepreneurship course participation. ${ }^{4}$ Overall, this gives us a sample of 8009 students of 120 different subject groups at 22 universities ${ }^{5}$. To analyze the temporal stability of the entrepreneurial climate on the organizational level, we also use GUESSS data from 2016.

Second, we used data from a comprehensive Germany-wide project to measure and evaluate the institutional infrastructure and the support mechanisms for student and academic entrepreneurship at universities, called 'Gründungsradar 2013' (in the following: 'university survey') (Grave et al., 2014). The Gründungsradar was conducted by the Stifterverband' ${ }^{6}$ and the German Federal Ministry of Economic Affairs and Energy. The project collects reliable data on a broad range of topics that are relevant for student and academic entrepreneurship (Institutional framework; entrepreneurship courses and events; start-up support; budget etc.)․ To the best of our knowledge, this project has collected the most comprehensive data on the support measures for entrepreneurship at universities in Germany. The project team contacted all universities in Germany of which 254 (65\%) took part in the study. ${ }^{8}$ Universities without any startup support, as for example most ecclesiastical colleges and colleges for education, could not take part in the survey. Thus, our sample only includes universities with a minimal commitment to entrepreneurship, which is, however, the case at most public universities in Germany.

\subsection{Students' perceptions of the entrepreneurial climate as dependent variable}

\footnotetext{
${ }^{4}$ In a robustness check, we use an augmented minimum number of 20 students per university subject group.

${ }^{5}$ A list of all 22 universities in our sample can be found in Appendix C.

${ }^{6}$ The Stifterverband is an association and has been established in 1920. It is a joint initiative of companies and foundations which is devoted to consulting, networking and promoting improvements in the fields of education, science and innovation in Germany. Its members consists of large and mid-size companies, company associations, donors and private individuals.

${ }^{7}$ For a summary see: www.stifterverband.com/gruendungsradar/2012/summary/index.html

${ }^{8}$ It should be noted the response rate of medium-sized (5,000-15,000 students) and large universities (more than 15,000 students) was more than $75 \%$. For small universities, colleges of art and private universities (incl. ecclesiastical colleges), the response rate was below $60 \%$, presumably, because some of them are not interested in the topic or do not offer any startup support.
} 
We measure students' perceptions of the entrepreneurial climate in their university as follows: Because there is no accepted measure of such a climate, we developed own items based on previous research on entrepreneurial climate (Geissler, 2013; Lüthje and Franke, 2004). Because our items were included in a large-scale study that covers different topics, we had to keep our measure brief. In line with our definition of climate, our items focus on the encouragement and support of entrepreneurial activities. We tested the content validity of our items with students at a mid-sized university in Germany. We also pretested the scale and excluded items with low factor loadings. The final scale consists of three items and has a very good reliability (Cronbach's Alpha: 0.87). Specifically, the respondents had to answer the following question:

"Please indicate to what extent you agree with the following statements about your university $(1=$ not at all, $7=$ completely $)$.

- At my university, students are encouraged to engage in entrepreneurial activities.

- The atmosphere at my university inspires me to develop ideas for new businesses.

- There is a favorable climate for becoming an entrepreneur at my university."

Our dependent variable is the average evaluation of these three statements.

\subsection{Independent variables}

We measure the share of the budget for the support of entrepreneurship-related activities using the university survey where university officials were asked to indicate the total budget for the support of entrepreneurship-related activities of their institution and the overall university budget.

We measure the degree of institutionalization of entrepreneurship at universities using three variables. First, we capture whether the university has a Chair of entrepreneurship or not. Second, we measure the share of faculties at every university that have an entrepreneurship officer. These officers are common in the German university system (Klandt, 2004). 
Typically, these people are academics or staff who coordinate entrepreneurship-related activities at their faculty and offer startup-advice for students or staff. Third, we measure the number of entrepreneurship or business plan competitions per year at the university.

We measure the share of students who have attended an entrepreneurship-related course using data from our student survey and distinguish between compulsory and elective courses. Based on theoretical and statistical reasoning we calculate these shares on the level of subject groups at universities rather than whole universities. ${ }^{9}$ Students will communicate regularly with other students studying the same subject. Thus, social context effects are likely to have an effect among students of the same subject group rather than among students of the whole university (Schneider and Reichers, 1983). Studies on faculty members also found them to identify with their disciplines or departments rather the university as a whole (Silver, 2003).

Table 1 presents a detailed description of all variables in our models; Table 2 shows their descriptive values and correlations, also including our dependent variable, students' perceptions of the entrepreneurial climate in their university.

\section{----- Include Tables 1 and 2 here -----}

\subsection{Control variables}

We follow Becker (2005) and only include control variables that are theoretically relevant and correlate with the dependent variable. While the theoretical relevance has been explained in the previous section, the correlations of our controls with the dependent variable is shown in table 2. All control variables correlate significantly with entrepreneurial climate. We include

\footnotetext{
${ }^{9}$ Following official classifications, we distinguish between the following eleven subject groups: Business / Management; Law; Economics; Other social sciences (including education); Engineering and architecture; Mathematics and natural sciences; Information science / IT; Medicine and health sciences; Agricultural science, forestry, and nutrition science; Linguistics and cultural studies (including psychology, philosophy, religion); Art, science of art
} 
subject dummies for ten different subject groups, with '(other) social sciences' being the reference group.

We measure the subject-specific reputation of universities as follows. Because there is no comprehensive ranking of all universities in our sample, we calculate the share of students in each university subject group who state that the main reason for studying at their respective university was its "strong reputation in general" (rather than the geographic proximity to hometown, the attractiveness of its location, costs, or other reasons).

\subsection{Methods}

We calculate linear multilevel regressions with random intercepts and cross-level interactions, using the software HLM 7, in which the students' perception of the entrepreneurial climate in their university acts as dependent variable (Hox, 2010; Raudenbush and Bryk, 2002). The basis for multi-level modelling is laid by the specific structure of GUESSS data. Unlike aggregated data, the micro data of GUESSS captures the hierarchical relationship between the individual student and the organizational environment that he or she belongs to. The organizational environment, in turn, includes a faculty level that is nested within a university level. The number of universities in our sample $(n=22)$, however, does not meet any of the suggested minimum numbers of upper level units as outlined by Hox (2010: 235). Hence, to avoid biased estimates arising from a limited sample size (Maas and Hox, 2005), we merge the faculty and the university level into one context level..$^{10}$

Compared to ordinary regression modelling, using multi-level analyses provides several advantages (Nezlek, 2011; Rabe-Hesketh and Skrondal, 2008; Snijders and Bosker, 2004). First, it helps to disclose the genuine nature of a nested data sample, in our case: students within organizations, and thus reduces the risk of ecological fallacies (Robinson, 1950). Second, it can

\footnotetext{
${ }^{10}$ We also refrain from modelling an extra regional level (relevant for 'population density') since the relation between universities and regions is characterized by a non-hierarchical ratio of almost one to one; in other words: almost every university is located in a separate region.
} 
be ascertained whether the organizational environment proves to be statistically relevant in addition to the individual level, and therefore may be regarded as autonomous dimensions in explaining climate perceptions. Third, it allows detecting possible cross-level interactions between the student and the organizational level in case that the impact of $\mathrm{X}$ on $\mathrm{Y}$ is further moderated by factors at the context level. Finally, ignoring the multi-level structure is likely to result in artificially smaller standard errors which in turn leads to smaller observed p-values and thus to inflated Type I error rates (Aarts et al., 2014).

As the null model (without any co-variates) reveals, the Intraclass Correlation Coefficient $\rho$ at the context level is about $12 \%$ (Table 3 ), indicating that $12 \%$ of the overall variance in students' perceptions of the entrepreneurial climate can be attributed to the between-group variance at the organizational level. As this finding is statistically significant, a multi-level analysis instead of an ordinary single-level regression should be applied for the advantages listed above.

Our estimation strategy consists of three consecutive analytical steps. First, we add the controls to the null model. Second, we include the hypotheses-relevant variables of both the student and the organizational level, before - in a third step - we test for theoretically derived cross-level interactions effects (Table 3). We run one model with alternative independent variables, measuring the entrepreneurship course participation by gender, and three robustness checks with subgroups of the whole sample to show the robustness of our findings (Table 4).

\section{Results}

\subsection{Multilevel analysis}

We run a number of different linear multilevel regression models to test our hypotheses (See Table 3). Model 1 is the so-called Null Model, which can be used to calculate the share in the variance on the different levels. While the majority of the variance in students' perceptions of the entrepreneurial climate is on the individual level, slightly more than $12 \%$ is on the context 
level. Model 2 only includes the control variables on the individual and the context level.

Model 3 also includes the hypothesized direct effects and Model 4 is the full model, including the cross-level interaction effects.

\section{----- include Table 3 here -----}

We do not find a significant relationship between the entrepreneurship budget of universities

(C5) and climate perceptions in any of the models. Thus, we have to reject Hypothesis 1.

However, there is some support for Hypothesis $2 a$ : Consistent across all models, there is, first, a significant positive relationship between the prevalence of entrepreneurship officers $\left(\mathrm{C}_{7}\right)$ and climate perceptions (Effect size: on average +0.2 on a 7 -point scale if $100 \%$ of all faculties have such an officer) and, secondly, the number of entrepreneurship competitions $\left(\mathrm{C}_{8}\right)$ and climate perceptions (on average +0.1 on a 7-point scale for every additional competition). While there is no direct effect of the existence of a Chair of entrepreneurship $\left(\mathrm{C}_{6}\right)$ on climate perceptions, there is one for students with entrepreneur parents $\left(\mathrm{X}_{2} * \mathrm{C}_{6}\right.$ in Model 4$)$, supporting Hypothesis $2 b$. The respective interaction plot shows that students with self-employed parents perceive a slightly more positive climate (on average +0.15 on a 7 -point scale) when a Chair of entrepreneurship exists. There is hardly any difference for students with non-entrepreneur parents (Figure 1). Overall, all investigated institutional characteristics have a positive effect on climate perceptions, for either all students or only those with self-employed parents.

\section{----- Include Figure 1 here -----}

Concerning the share of fellow students who have taken an entrepreneurship course, we find a positive significant effect for compulsory courses $\left(\mathrm{C}_{10}\right)$, supporting Hypothesis $3 a$, but not for elective courses ( $\mathrm{C} 9)$, leading to a rejection of Hypothesis $3 b$. We find partial support for our Hypothesis $3 c$, that climate perceptions of male students are more likely to be positively influenced by the prevalence of fellow students who have visited a compulsory entrepreneurship 
course $\left(\mathrm{X}_{1} * \mathrm{C}_{10}\right.$ in Model 4$)$. The interaction plot suggests that there is almost no effect for women but a substantial positive effect for men (on average +0.4 on a 7 -point scale if $40 \%$ of their fellow students participated; see Figure 2). To analyze whether this finding is simply the result of gender differences in the perception of fellow students, or whether men are indeed more likely to interact with other men, as hypothesized, we ran a separate analysis where we investigate the effect of the share of fellow male students who have participated in an entrepreneurship course (Alternative Model 1 in Table 4 and interaction plot in Figure 3). The result is similar to the main model: When their fellow male students have participated in a compulsory entrepreneurship course, men are more likely to perceive the entrepreneurial climate as positive whereas there is no effect for women. This result suggests that male students are more likely to interact and to be influenced by fellow male students. Thus, even after controlling for individual course participation, male students are affected by the share of fellow students who have participated in an entrepreneurship course as obligatory part of their normal studies. This result suggests that requiring more students to take a course in entrepreneurship has two effects. First, it directly influences the climate perceptions of course participants, as indicated by the significant positive individual level effect (X5). Secondly, it has a social effect on fellow male students independent from their individual course participation, as indicated by the positive interaction effect. It should be noted that elective course participation also has a positive and even stronger direct effect on climate perceptions of participants; however, we do not find evidence for a broader social effect.

\section{----- Include Figure 2 and Figure 3 here -----}

Concerning the individual level controls, it is important to note that gender does not influence entrepreneurial climate perceptions when controlling for subject of study, entrepreneurship course participation and other variables.

\subsection{Robustness check: Subgroup analyses}


We calculated a number of alternative models to control for the robustness of our findings. Alternative Model 2, excluding two universities with potentially unrepresentative samples (see Appendix A) and alternative Model 3, with a higher minimum number of 20 respondents per subject group, provide almost the same results as the full model.

As a further robustness check, we only look at students with an affinity for entrepreneurship and calculate the entrepreneurial climate for this subgroup of students (see Model 4 in Table 4) ${ }^{11}$. We do so because Students without an affinity for entrepreneurship might be less able to evaluate the entrepreneurial climate and might evaluate it solely on the basis of their general perception of the quality of the university, i.e. a Halo effect (Boatwright et al., 2008). On the other hand, students with an affinity for entrepreneurship should have an informed understanding about the respective climate and should be less prone to a Halo-effect. In our robustness analysis, we find slightly different results than in our main model. While the effect of most institutional characteristics (Chair of ent.; faculties with ent. officers; number of ent. competitions; number of students etc.) is unchanged, there are interesting differences concerning ent. course participation and general reputation of the university. The insignificance of the general reputation of the university $\left(\mathrm{C}_{4}\right)$ suggests, that the climate perceptions of the general student population are indeed - at least partly - the result of a Halo effect. In addition, students with an affinity for entrepreneurship are not affected by the share of fellow students who have participated in a compulsory course (like for students overall) but by the share of fellow students who have participated in an elective course, suggesting a different kind of peer effect. Students with an affinity for entrepreneurship can be assumed to have a higher likelihood of self-selecting into specific universities. Thus, the results of Model 4 might also be interpreted as a robustness check for self-selection.

\footnotetext{
${ }^{11}$ We code students who are trying to start a new business, who are already self-employed or who have attended at least one entrepreneurship course as having an affinity for entrepreneurship and all others as having no affinity.
} 


\subsection{Relative importance of the context level controls}

It is important to point out that our model is able to explain the variance of climate perceptions on the context level to a substantial degree. When only including the control variables on the context level, the model already explains $85 \%$ of the variance on this level (Model 2 , Table 3). The additional impact of our independent variables on the context level is relatively small. (Models 3 and 4). To analyze which of the control variables has the largest effect, we ran the model with different combinations of context level controls only. As can be seen in Table 5, the size of the university (number of students) and its perceived reputation explain already more than $83 \%$ of the overall variance on the context level. To illustrate the strong effect of structural characteristics, we take the examples of the smallest (Technical University of Applied Sciences Wildau, 4,150 students) and the largest university in our sample (RuhrUniversity Bochum, 41,500 students). According to the regression coefficients of the full model (4) (Table 3), this model predicts better climate perceptions of +1.0 (on a 7-point scale) for Wildau (compared to Bochum) just because of being much smaller and a university of applied sciences. In comparison to the effect of intentional entrepreneurship measures, captured in our hypotheses, this effect can be considered as substantial.

\section{----- Include Table 5 here}

\subsection{To what degree are climate perceptions shared?}

As explained above, individual climate perceptions can be aggregated to the group level, if there is a certain level of agreement concerning the climate among group members (Patterson et al., 2005). As suggested by LeBreton and Senter (2007), we calculate the inter-rater agreement IRA ( $\left.\mathrm{r}_{\mathrm{wg}}\right)$ as indicator of agreement (using the uniform distribution as reference). We calculate the IRA at the level of university subject groups because students are more likely to interact with students studying the same or a related subject at the university. Other types of 
organizational climate are also frequently measured at the level of workgroups or departments (Bollmann and Krings, 2016; Zohar and Luria, 2005). This level of analysis is also supported by the IRA values: The average interrater agreement for whole universities is smaller than for individual subject groups at universities. In our sample, the average IRA $\left(r_{w g}\right)$ is 0.67 , which can be described as moderate level of agreement. For 47 subject-group values (39\%), the interrater agreement is above .70, indicating a strong agreement (LeBreton and Senter, 2008). This result suggests that students' perceptions of the entrepreneurial climate in their university are to some extent shared and could also be aggregated to a measure of the organizational climate for entrepreneurship among students.

As test of the reliability of this measure, we investigate the temporal stability of the entrepreneurial climate on the organizational level. The identical 3-item measure of entrepreneurial climate has also been used in the 2016 version of the GUESSS study. We calculate the subject group organizational climate for entrepreneurship in the same way for 2016 and 2013. 16 German universities took part in both surveys (GUESSS 2013 and GUESSS 2016) and had sufficiently large samples to allow the calculation of the entrepreneurial climate for one or more subject-groups in both years $(n>=10)$. Overall, we can compare the entrepreneurial climate for 64 subject group values. With a correlation of .844, the statistical association between the 2013 and 2016 values is strong and highly significant. Figure 4 shows a plot of the values.

\section{----- Include Figure 4 about here -----}

\section{Discussion}

\subsection{Hypothesized effects: statistically significant but small}

Our study investigates students' perceptions of the entrepreneurial climate in their university. The results suggest that individual and contextual factors influence such climate perceptions. As hypothesized, university measures that aim at fostering entrepreneurial thinking and acting 
at universities do have a statistically significant positive effect, which is however small: Students feel more inspired to develop ideas for new businesses and to engage in entrepreneurial activities when there are entrepreneurship competitions and faculty entrepreneurship officers at their university. We do not find evidence for an effect of the share of the budget for the support of entrepreneurial activities. Thus, not the budget itself but the offerings financed from this budget seem to be important for the entrepreneurial climate. Another explanation for this non-finding might be that our budget measure also includes the possible costs of a Chair of entrepreneurship, which is typically not only involved in teaching but also in research.

The significance of a number of individual variables demonstrates that climate perceptions are not purely dependent on characteristics of organizations, as postulated by early theorists of organizational climate (Payne and Pugh, 1976). Instead, contextual characteristics have a different impact depending on students' personal characteristics. For example, a Chair of entrepreneurship only affects climate perceptions of students with self-employed parents. Presumably, these students are better able to evaluate why entrepreneurship is important and in how far such a chair might be helpful for their personal future career. Thus, the entrepreneurial climate at public universities does not only depend on what the university does to support entrepreneurship but also on who is being admitted to the university.

While a broad literature has investigated the effect of entrepreneurship education on the individual formation of human capital and entrepreneurial intentions (for a review see: Martin et al., 2013), our results suggest that the participation of students in entrepreneurship courses also has broader, social effects. Our results suggest that people interact with fellow students, who have participated in entrepreneurship courses, and develop a more positive view concerning entrepreneurship support at their university even if they themselves have not participated in such a course. Such peer effects evolve in different ways for people with and without an affinity for entrepreneurship. The general student population can be assumed not to have a strong affinity towards entrepreneurship and starting a business. For them, having 
fellow students that have participated in a compulsory entrepreneurship course improves individual climate perceptions. As discussed above, the development of an organizational climate is based on a social process of sensemaking that can be affected by how sensegiving events are organized and how participation is regulated (Maitlis, 2005). The importance of compulsory rather than elective courses appears counterintuitive at first glance, yet, it can be explained by the nature of university education and the constant challenge to socialize newcomers into the university setting. Students typically only stay at universities for some years. Given their usually limited affinity towards entrepreneurship, it might be necessary to regularly confront new cohorts of students with the concept of entrepreneurship in order to interest them in this topic, sensitize them for respective university offerings and start a discussion about the relevance of entrepreneurship with their fellow students. Requiring students to participate in an entrepreneurship course might act as a triggering event and might foster a discussion among students about the importance of this subject and then start an 'entrepreneurial spiral' that affects the whole organization (Shepherd et al., 2010). As for other types of climate (Niskanen, 1994), students' perceptions of the entrepreneurial climate are likely to be affected by binding rules and practices that a university imposes on its students rather than voluntary offerings whose importance might not be perceived by students without an affinity for starting a business.

For students with an affinity for entrepreneurship, the situation is different. These students are interested in the topic and can be expected to want to improve their knowledge and capabilities for starting a business, anyhow. In addition, they are likely to interact more with other students with an affinity for entrepreneurship. Our findings are in line with these assumptions. For students with an affinity for entrepreneurship, having fellow students who have participated in elective courses has a positive, albeit weakly significant, effect, whereas there is no effect for compulsory courses. Thus, these students benefit from a social context of students with a similar interest who have voluntarily participated in respective offerings. 
Overall, these results suggest that entrepreneurial climate perceptions develop along different routes for students with and without an affinity for entrepreneurship. The existence of different mechanisms of climate formation might also explain why overall, the agreement of students concerning the entrepreneurial climate is only moderate, as demonstrated by the interrater-agreement analysis.

\subsection{Importance of general university characteristics}

While we find full or partial support for our hypotheses on contextual characteristics, we have to acknowledge that - overall - our hypothesized antecedents only have a relatively modest effect on climate perceptions. Our control variables, i.e. universities' structural characteristics (especially its size) and its reputation, determine the entrepreneurial climate to a large extent. The implication from this finding is that universities might develop a reasonably positive entrepreneurial climate without explicit policy measures to foster it, or, framed differently, large research universities with only a modest general reputation will find it difficult to develop a positive entrepreneurial climate. Concerning general reputation, there are three possible explanations for its strong effect. First, universities with a better reputation can be assumed to provide a higher quality education to their students. As a result, students from these universities will feel better qualified for their future career, which also includes the possibility to become entrepreneurially active. This interpretation is in line with the observation that formal human capital is an important predictor of the decision to become entrepreneurially active (Davidsson and Honig, 2003). Studies have shown that graduates from top universities are more likely to choose entrepreneurial occupations (Daghbashyan and Hårsman, 2014) and earn more when becoming an entrepreneur ( $₫$ stebro et al., 2012). Thus, attending a high-quality education is likely to be perceived as supportive for an entrepreneurial career. Second, universities with a better reputation might be able to attract better-qualified and motivated students (Schneider, 1983). This might lead to a more stimulating entrepreneurial environment, 
as - for example - in the case of top universities like the MIT (Åstebro et al., 2012). In Germany, universities with a good reputation usually impose entry restrictions and only accept selected students with very good grades in their university-entrance diploma. Third, the strong impact of reputation might be the result of a Halo-effect, where a person's overall evaluation or impression of the university quality leads her to also evaluate the entrepreneurial climate in a similar way (Boatwright et al., 2008). Similar to the results in other organizational settings (e.g., Sine, Shane, \& Gregorio, 2003), our results suggest that the general student population is also affected by a Halo effect when evaluating the entrepreneurial climate. The theoretical argument behind this effect is that reputation works as a signaling effect in uncertain situations. Quality expectations of uncertain characteristics are influenced by the perceived quality of other characteristics (e.g., university teaching, university research). Thus, students may attribute their perceptions of the general university reputation to the entrepreneurship domain. Similar reputation effects have also been found in academic entrepreneurship and technology transfer (Di Gregorio and Shane, 2003; Sine et al., 2003). This phenomena seems to be especially strong if individuals evaluate ambiguous attributes (Nisbett and Wilson, 1977). It is somewhat more difficult to explain the strong negative effect of size. Small universities might be perceived as more supportive concerning entrepreneurship because students simply find it easier to obtain relevant information and approach advisors and mentors. Again, students might attribute their experience of dealing with the university bureaucracy in general to the evaluation of entrepreneurship support.

Implicitly, policy reports sometimes equate a positive entrepreneurial climate with the existence of relevant support institutions and other supportive framework conditions for starting a business (Grave et al., 2014). Our results demonstrate that this view is partly misleading because students' perceptions of the entrepreneurial climate are only to some degree dependent on the actual entrepreneurship support measures but also strongly influenced by general university characteristics. 


\subsection{Public universities in Germany as study context}

We have to acknowledge that, on average, the students in our sample evaluate the entrepreneurial climate at German public universities as mediocre only. The mean evaluation is 3.59 on a scale from 1 to 7 ; at some large universities it is only 3.0. One reason for this disillusioning finding might be that the support of entrepreneurial activities is still a relatively recent phenomenon at public universities in Germany (Klandt, 2004; Walter et al., 2013). While many universities in Germany have implemented measures to foster entrepreneurship and research commercialization, also described as universities' third-mission (Etzkowitz et al., 2000), they are still bound by legal rigidities and dependent on ministerial bureaucracies and public funding (Ash, 2006). Because of this, many entrepreneurship professorships have been realized on the basis of private donations rather than public investments (Schmude et al., 2008). In his review of the state of entrepreneurship education and research in Germany, Klandt (2004, p. 300) concluded that the "shortcomings at German universities as regards entrepreneurship cannot be eliminated by setting up a few entrepreneurship professorships." Overall, the universities in our sample spend only $0.39 \%$ of their total budget on the support of entrepreneurship (see Table 2). Thus, it might be naïve to expect major effects of entrepreneurship support measures on climate perceptions of the general student population. The modest agreement among students concerning the entrepreneurial climate (moderate IRA values) also suggests that, at most public universities in Germany, there is no intense discussion about the importance of this topic and the respective framework conditions for starting a business, which would have led to a higher degree of similarity of climate perceptions(Schneider et al., 2002). Presumably, stronger and coordinated efforts would be required to achieve more positive and uniform perceptions of the entrepreneurial climate.

Despite these reservations, our results show that entrepreneurial climate perceptions are to some extent shared among students of the same disciplinary group at universities, 
which suggests that entrepreneurial climate can also be considered as an organizational phenomenon (Schneider and Reichers, 1983). We demonstrate the temporal stability of the organizational climate for entrepreneurship at German universities, which is another strong indication that it is indeed an organizational property that is distinguishable from individual climate evaluations. While the student population changes regularly at universities, the entrepreneurial climate seems to remain largely stable over time.

\section{Limitations and further research}

Overall, our study demonstrates the applicability of the concepts of psychological and organizational climate to students at universities and we encourage further research on these important constructs. While our study differentiates between the effect of elective and compulsory courses on entrepreneurial climate, future studies should examine the duration, content, and organization of these courses in more detail. One important and partly unexpected result of our study that deserves further research is the relationship between climate perceptions and universities' general characteristics, like size and reputation. Additionally, the relationship between organizational and regional climates, and the long-term effects of the entrepreneurial climate are fruitful areas for further research.

Studying the contextual influences on climate perceptions is challenging because one needs data from a number of different organizations. While our sample of 120 subject group values from 22 universities is substantially larger than that of previous studies (Hunter et al., 2011), it is still a relatively modest number which does not allow analyses with a greater degree of precision. In addition, critiques might argue that our measurement of the entrepreneurial climate is rather crude. We were only able to measure entrepreneurial climate using a three-item measure.

Our measures of share of fellow students with entrepreneurship course participation $\left(\mathrm{C}_{9}\right.$ and $\left.\mathrm{C}_{10}\right)$ and general reputation $\left(\mathrm{C}_{4}\right)$ have been calculated on the basis of a limited number 
of cases. We control for individual course participation $\left(\mathrm{X}_{4}\right.$ and $\left.\mathrm{X}_{5}\right)$ and individual reason for university choice (reputation) $\left(\mathrm{X}_{6}\right)$ to avoid biased effects of the aggregate values (because the value of the individual respondent also went into the calculation of the average value of the respective subject group). However, the aggregate values might only have a low reliability because in some cases they are only based on less than 20 cases. Our robustness test with a minimum number of 20 cases (Alt. Model 2 in Table 4) delivered the same results as with the full sample.

While we control for one important reason for university choice (strong reputation in general), we cannot rule out the possibility that entrepreneurial students self-select into specific universities, which might have influenced the results.

The organizational environment includes a subject-group level that is nested within a university level. However, because of a limited number of universities in our sample $(n=22)$ we merged the subject-group and the university level into one context level, which might have biased our estimates. Future studies are encouraged to conduct a three-level analysis.

Finally, our study is set in the context of public universities in Germany and its results might not be generalizable to universities in other countries.

\section{Conclusions and policy implications}

Public universities form the great majority of all universities in the European higher education system. Thus, measures to improve the entrepreneurial climate are particularly required for universities of this type. Our results suggest that climate perceptions are affected in different ways for students with and without an affinity for entrepreneurship. While establishing a support infrastructure and offering voluntary entrepreneurship courses encourages students with an interest in entrepreneurship, the general student population usually only has a vague idea in how far their university supports entrepreneurial thinking and acting. Their respective perceptions are strongly affected by general perceptions of the university quality and size. Hence, 
large research universities should be aware that they might have to make a substantial effort to overcome the moderate or even negative perceptions that currently prevail among their students. Universities that aim at creating an encompassing and positive entrepreneurial climate among all students should consider to foster the participation in entrepreneurship courses and include basic entrepreneurship content in different degree programs, as demanded by previous policy reports (Kauffman Foundation, 2008). As a first step, we encourage universities to include the entrepreneurial climate as an indicator in their strategic decision making process and to regularly monitor and analyze this important variable.

\section{Acknowledgements}

We are very grateful for comments provided by editor Ben Martin and two anonymous referees, Bart Clarysse, Martin Lukeš, and Erik Monsen. Previous versions of this paper have been presented at the Rencontres de St-Gall 2016, St.Gallen, the AOM 2017 Annual Meeting, Atlanta, and the 2017 Frontiers in MOC and TIM Conference, Zürich. Any errors remain ours alone. 


\section{Appendix A: The GUESSS data collection in Germany and its representativeness}

The 22 universities in our sample sent out the link to the online survey themselves, using their general list of student emails. The students received an email with a neutrally worded invitation to participate in a study on their 'future occupational choice' and a link to the online survey. As an incentive to participate, a lottery of five times 100 Euro was conducted. We did not send a reminder email because the email policy of most participating universities did not allow us to do so. Using general university email list is a feasible way - and probably the only practically viable way - to reach all students of a university (Dillman et al., 2009, p.44). However, this method also has limitations because, according to university officials, students with multiple email accounts might not regularly consult their university email account. Some universities also included the request to participate in the survey in an overall newsletter that was sent to all students. Thus, while we can assure that our request to participate in the survey went to all students, we cannot be sure that all students read the email or paid attention to our survey in due course, which makes it difficult to calculate a true response rate. Overall, the participation rate to the GUESSS online survey at the 22 universities was 4\%. Although this rate is comparable to other online-surveys among the general student population (Porter and Whitcomb, 2003) and there is no consensus on what an acceptable response rate is (Mellahi and Harris, 2016), this rate can be considered as low and questions the representativeness of our data. Therefore, we checked for a non-response bias and compared our sample to the general student population at these universities.

\section{Controlling for a non-response bias}

We controlled for non-response bias by distinguishing between three groups: early, middle, and late respondents, the assumption being that non-respondents are more similar to late respondents than to early respondents (Dooley and Lindner, 2003). We compare early and late respond- 
ents using t-tests for equality of means and find no statistically significant differences concerning parental self-employment, participation in entrepreneurship courses, and - most importantly - our dependent variable entrepreneurial climate between the two groups. There is a significant difference concerning gender, with late respondents being more likely to be female. However, our interpretation of this finding is that, because male students spend more time per day using the internet (Kleimann et al., 2008), they are more likely to be early respondents. Overall, the share of female respondents is even slightly higher in our sample than at German universities in general, which is contrary to the assumption that women are more likely to be non-respondents. Thus, overall our results suggest that a non-response bias is not present. Lastly, our dependent variable (entrepreneurial climate) is very stable over time on the organizational level $(\mathrm{r}=.844$; see figure 4$)$, which we also interpret as evidence that our samples can be used to obtain reliable estimates of the entrepreneurial climate at universities.

\section{Comparing the sample to the overall student population}

Secondly, we also compared the sample to the overall student population at the 22 universities. Overall, female students are significantly overrepresented in our sample (Share female students in the sample: $56 \%$; share of females at universities overall: $41 \%$ ). However, as we control for gender in our multilevel analysis, this should not cause any biased results. There are two universities, where women are considerably overrepresented compared to the overall student population, Mittweida University of Applied Sciences and Münster University of Applied Sciences. As a robustness check, we ran the analysis without these two universities (Alternative Model 3 in Table 4) with almost identical results. Women might be less likely to participate in an entrepreneurship course. Therefore, estimates about the share of students who have participated in an entrepreneurship course might be biased. As explained above, we ran a model where we only look at the share of male students who have participated in an entrepreneurship course, 
again with the same results (Alt. Model 1, Table 4). Concerning subject of study, overall, students from the social sciences (including management etc.) and information technology are slightly overrepresented and students from medicine and science of art are underrepresented in our sample compared to the total population at the 22 investigated universities. At some individual universities, students from some subject groups are substantially overrepresented (Fulda: Engineering and architecture; Mainz: Mathematics and natural sciences; Münster: Agricultural sciene, forestry and nutrition sciences; Zwickau: Medicine and health sciences). We can only speculate about the reasons for these deviations; some may simply be caused by a relatively small population of students of a specific subject group at a university. However, as we control for subject group and calculate some key variables specifically on the level of subject groups, these deviations should not bias the results.

To sum up, while our response rate is low, we do not find evidence that our results would be different with a higher response rate. 
Appendix B: Universities included in this study

\begin{tabular}{|l|c|c|c|}
\hline & $\begin{array}{c}\text { University } \\
\text { of applied } \\
\text { sciences }\end{array}$ & $\begin{array}{c}\text { Total number } \\
\text { of students } \\
(2013 / 14)\end{array}$ & $\begin{array}{c}\text { number of } \\
\text { subject- } \\
\text { groups in our } \\
\text { sample }\end{array}$ \\
\hline Aachen, University of Applied Sciences & yes & 12,370 & 4 \\
\hline Bayreuth, University & no & 13,030 & 9 \\
\hline Berlin, University of Applied Sciences (HTW) & yes & 13,010 & 6 \\
\hline Bochum, University & no & 41,500 & 8 \\
\hline Bonn-Rhein-Sieg, University of Applied Sciences & yes & 6,950 & 5 \\
\hline Chemnitz, Technical University & no & 11,230 & 6 \\
\hline Cologne, University of Applied Sciences & yes & 22,800 & 4 \\
\hline Cottbus, Technical University (BTU) & no & 9,400 & 5 \\
\hline Dortmund, University of Applied Sciences & yes & 12,250 & 4 \\
\hline Flensburg, University of Applied Sciences & yes & 3,940 & 3 \\
\hline Fulda, University of Applied Sciences & yes & 7,100 & 5 \\
\hline Hannover, University & no & 23,900 & 9 \\
\hline Kassel, University & no & 22,880 & 8 \\
\hline Mainz, University of Applied Sciences & yes & 4,930 & 5 \\
\hline Mannheim, University of Applied Sciences & yes & 5,200 & 3 \\
\hline Mittweida, University of Applied Sciences & yes & 6,300 & 5 \\
\hline Münster, University of Applied Sciences & yes & 12,680 & 6 \\
\hline Siegen, University & no & 18,600 & 8 \\
\hline Stuttgart, Media University & yes & 4,200 & 5 \\
\hline Wildau, Technical University of Applied Sciences & yes & 4,150 & 4 \\
\hline Wismar, University of Applied Sciences & yes & 8,020 & 4 \\
\hline Zwickau, University of Applied Sciences & yes & 4,790 & 4 \\
\hline Total & $\mathbf{6 8 \%}$ & $\mathbf{2 6 9 , 2 3 0}$ & $\mathbf{1 2 0}$ \\
\hline
\end{tabular}




\section{References}

Aarts, E., Verhage, M., Veenvliet, J. V, Dolan, C. V, van der Sluis, S., 2014. A solution to dependency: Using multilevel analysis to accommodate nested data. Nat. Neurosci. 17, 491-496. doi: $10.1038 / \mathrm{nn} .3648$

Abreu, M., Grinevich, V., 2013. The nature of academic entrepreneurship in the UK: Widening the focus on entrepreneurial activities. Res. Policy 42, 408-422. doi:10.1016/j.respol.2012.10.005

Ahl, H., 2006. Why Research on Women Entrepreneurs Needs New Directions. Entrep. Theory Pract. 30, 595-621. doi:10.1111/j.1540-6520.2006.00138.x

Ancis, J., Sedlacek, W., Mohr, J., 2000. Student perceptions of campus cultural climate by race. J. Couns. 78, 180-185. doi:10.1002/j.1556-6676.2000.tb02576.x

Anderson, C.S., 1982. The Search for School Climate: A Review of the Research. Rev. Educ. Res. 52, $368-420$.

Ash, M.G., 2006. Bachelor of What, Master of Whom? The Humboldt Myth and Historical Transformations of Higher Education in German-Speaking Europe and the US. Eur. J. Educ. 41, 245-267. doi:10.1111/j.1465-3435.2006.00258.x

Ashforth, B.E., 1985. Climate Formation: Issues and Extensions. Acad. Manag. Rev. 10, 837-847.

Åstebro, T., Bazzazian, N., Braguinsky, S., 2012. Startups by recent university graduates and their faculty: Implications for university entrepreneurship policy. Res. Policy 41, 663-677. doi:10.1016/j.respol.2012.01.004

Baughn, C.C., Chua, B.-L., Neupert, K.E., 2006. The Normative Context for Women's Participation in Entrepreneruship: A Multicountry Study. Entrep. Theory Pract. 30, 687-708.

Beaudry, C., Schiffauerova, A., 2009. Who's right, Marshall or Jacobs? The localization versus urbanization debate. Res. Policy 38, 318-337. doi:10.1016/j.respol.2008.11.010

Becher, T., 1994. The Significance of Disciplinary Differences. Stud. High. Educ. 19, 151-161.

Becker, T.E., 2005. Potential Problems in the Statistical Control of Variables in Organizational Research: A Qualitative Analysis With Recommendations. Organ. Res. Methods 8, 274-289. doi:10.1177/1094428105278021

Bercovitz, J., Feldman, M., 2008. Academic Entrepreneurs: Organizational Change at the Individual Level. Organ. Sci. 19, 69-89. doi:10.1287/orsc.1070.0295

Bergmann, H., 2017. The formation of opportunity beliefs among university entrepreneurs: an empirical study of research- and non-research-driven venture ideas. J. Technol. Transf. 42, 116140. doi:10.1007/s10961-015-9458-z

Bergmann, H., Hundt, C., Sternberg, R., 2016. What makes student entrepreneurs? On the relevance (and irrelevance) of the university and the regional context for student start-ups. Small Bus. Econ. 47, 53-76. doi:10.1007/s11187-016-9700-6

Boatwright, P., Kalra, A., Zhang, W., 2008. Research Note-Should Consumers Use the Halo to Form Product Evaluations? Manage. Sci. 54, 217-223. doi:10.1287/mnsc.1070.0742

Bollmann, G., Krings, F., 2016. Workgroup Climates and Employees' Counterproductive Work Behaviours: A Social-Cognitive Perspective. J. Manag. Stud. 53, 184-209. doi:10.1111/joms.12167

Borucki, C.C., Burke, M.J., 1999. An examination of service-related antecedents to retail store performance. J. Organ. Behav. 20, 943-962. doi:10.1002/(SICI)10991379(199911)20:6<943::AID-JOB976>3.0.CO;2-9

Cureton, S.R., 2003. Race-Specific College Student Experiences on a Predominantly White Campus. J. Black Stud. 33, 295-311.

Daghbashyan, Z., Hårsman, B., 2014. University choice and entrepreneurship. Small Bus. Econ. 42, 729-746. doi:10.1007/s11187-013-9501-0

Daraio, C., Bonaccorsi, A., Geuna, A., Lepori, B., Bach, L., Bogetoft, P., Cardoso, M.F., CastroMartinez, E., Crespi, G., de Lucio, I.F., Fried, H., Garcia-Aracil, A., Inzelt, A., Jongbloed, B., Kempkes, G., Llerena, P., Matt, M., Olivares, M., Pohl, C., Raty, T., Rosa, M.J., Sarrico, C.S., Simar, L., Slipersaeter, S., Teixeira, P.N., Eeckaut, P. Vanden, 2011. The European university 
landscape: A micro characterization based on evidence from the Aquameth project. Res. Policy 40, 148-164. doi:10.1016/j.respol.2010.10.009

Davidsson, P., Honig, B., 2003. The role of social and human capital among nascent entrepreneurs. J. Bus. Ventur. 18, 301-331. doi:10.1016/S0883-9026(02)00097-6

Dawson, J.F., Gonzalez-Roma, V., Davis, A., West, M., 2008. Organisational climate and climate strength in UK hospitals. Eur. J. Work Organ. Psychol. 17, 89-111. doi:10.1080/13594320601046664

DeJoy, D.M., Schaffer, B.S., Wilson, M.G., Vandenberg, R.J., Butts, M.M., 2004. Creating safer workplaces: assessing the determinants and role of safety climate. J. Safety Res. 35, 81-90. doi:10.1016/j.jsr.2003.09.018

Denison, D.R., 1996. What is the Difference between Organizational Culture and Organizational Climate? A Native's Point of View on a Decade of Paradigm Wars. Acad. Manag. Rev. 21, 619654.

DeWitt, C.D., Simon, H.A., 1958. Selective Perception: A Note on the Departmental Identifications of Executives. Sociometry 21, 140-144.

Di Gregorio, D., Shane, S., 2003. Why do some universities generate more start-ups than others? Res. Policy 32, 209-227.

Dillman, D.A., Smyth, J.D., Christian, L.M., 2009. Internet, Mail, and Mixed-Mode Surveys: The Tailored Design Method, 3rd ed. Wiley, Hoboken, NJ.

Djokovic, D., Souitaris, V., 2008. Spinouts from academic institutions: a literature review with suggestions for further research. J. Technol. Transf. 33, 225-247. doi:10.1007/s10961-006-90004

Dooley, L.M., Lindner, J.R., 2003. The Handling of Nonresponse Error. Hum. Resour. Dev. Q. 14, 99-110. doi:10.1002/hrdq.1052

Eesley, C., Wang, Y., 2017. Social influence in career choice: Evidence from a randomized field experiment on entrepreneurial mentorship. Res. Policy 46, 636-650. doi:10.1016/j.respol.2017.01.010

Eickelpasch, A., Fritsch, M., 2005. Contests for cooperation-A new approach in German innovation policy. Res. Policy 34, 1269-1282. doi:10.1016/j.respol.2005.02.009

Etzkowitz, H.A., Webster, A., Gebhardt, C., Terra, B.R.C., 2000. The future of the university and the university of the future: evolution of ivory tower to entrepreneurial paradigm. Res. Policy 29, 313-330. doi:10.1016/S0048-7333(99)00069-4

European Commission, OECD, 2012. A Guiding Framework for Entrepreneurial Universities.

Fini, R., Grimaldi, R., Santoni, S., Sobrero, M., 2011. Complements or substitutes? the role of universities and local context in supporting the creation of academic spin-offs. Res. Policy 40, 1113-1127. doi:10.1016/j.respol.2011.05.013

Frank, A., Krempkow, R., Mostovova, E., 2017. Gründungsradar 2016. Essen.

Geissler, M., 2013. Determinanten des Vorgründungsprozesses. Springer Fachmedien Wiesbaden, Wiesbaden. doi:10.1007/978-3-658-01665-4

Geissler, M., Jahn, S., Haefner, P., 2010. The entrepreneurial climate at universities: the impact of organizational factors, in: Smallbone, D., Leitao, J., Raposo, M., Welter, F. (Eds.), The Theory and Practice of Entrepreneurship. Edward Elgar Publishing, Cheltenham, UK / Northampton, MA, pp. 12-31.

Gioia, D.A., Chittipeddi, K., 1991. Sensemaking and Sensegiving in Strategic Change Initiation. Strateg. Manag. J. 12, 433-448.

Glick, W.H., 1985. Conceptualizing and Measuring Organizational and Psychological Climate: Pitfalls in Multilevel Research. Acad. Manag. Rev. 10, 601-616.

Grave, B.S., Hetze, P., Kanig, A., 2014. Gründungsradar 2013. Stifterverband für die Deutsche Wissenschaft, Essen.

Gupta, V.K., Turban, D.B., Wasti, S.A., Sikdar, A., 2009. The Role of Gender Stereotypes in Perceptions of Entrepreneurs and Intentions to Become an Entrepreneur. Entrep. Theory Pract. 33, 397-417. doi:10.1111/j.1540-6520.2009.00296.x 
Heilman, M.E., 2001. Description and prescription: How gender stereotypes prevent women's ascent up the organizational ladder. J. Soc. Issues 57, 657-674. doi:10.1111/0022-4537.00234

Herrington, M., Kew, P., 2017. Global Entrepreneurship Monitor, Global Report 2016/17.

Hox, J., 2010. Multilevel Analysis: Techniques and Applications, 2nd ed. Routledge, New York.

Hunter, E.M., Perry, S.J., Currall, S.C., 2011. Inside multi-disciplinary science and engineering research centers: The impact of organizational climate on invention disclosures and patents. Res. Policy 40, 1226-1239. doi:10.1016/j.respol.2011.05.024

Huyghe, A., Knockaert, M., 2015. The influence of organizational culture and climate on entrepreneurial intentions among research scientists. J. Technol. Transf. 40, 138-160. doi:10.1007/s10961-014-9333-3

James, L.R., Choi, C.C., Ko, C.-H.E., McNeil, P.K., Minton, M.K., Wright, M.A., Kim, K., 2008. Organizational and psychological climate: A review of theory and research. Eur. J. Work Organ. Psychol. 17, 5-32. doi:10.1080/13594320701662550

James, L.R., Hater, J.J., Gent, M., Bruni, J., 1978. Psychological climate: Implications from cognitive social learning theory and interactional psychology. Pers. Psychol. 31, 783-813. doi:10.1111/j.1744-6570.1978.tb02124.x

James, L.R., Sells, S.B., 1981. Psychological Climate: Theoretical Perspectives and Empirical Research, in: Magnusson, D. (Ed.), Toward A Psychology of Situations: An Interactional Perspective. Lawrence Erlbaum Associates, Hillsdale, NJ, pp. 275-295.

Kauffman Foundation, 2008. Entrepreneurship in American Higher Education. Kansas City.

Kenney, M., Goe, W.R., 2004. The role of social embeddedness in professorial entrepreneurship: a comparison of electrical engineering and computer science at UC Berkeley and Stanford. Res. Policy 33, 691-707. doi:10.1016/j.respol.2003.11.001

Klandt, H., 2004. Entrepreneurship Education and Research in German-Speaking Europe. Acad. Manag. Learn. Educ. 3, 293-301.

Kleimann, B., Özkilic, M., Göcks, M., 2008. Studieren im Web 2.0, HISBUS-Kurzinformationen Nr. 21. Hannover.

Kuenzi, M., Schminke, M., 2009. Assembling Fragments Into a Lens: A Review, Critique, and Proposed Research Agenda for the Organizational Work Climate Literature. J. Manage. 35, 634717. doi:10.1177/0149206308330559

Kulicke, M., 2014. 15 Years of EXIST "University-based start-up programmes," Working paper from the scientific research supporting the "EXIST - University-based start-up programmes." Karlsruhe.

Kuratko, D.F., 2005. The Emergence of Entrepreneurship Education: Development, Trends, and Challenges. Entrep. Theory Pract. 29, 577-597.

Laspita, S., Breugst, N., Heblich, S., Patzelt, H., 2012. Intergenerational transmission of entrepreneurial intentions. J. Bus. Ventur. 27, 414-435. doi:10.1016/j.jbusvent.2011.11.006

LeBreton, J.M., Senter, J.L., 2008. Answers to 20 Questions About Interrater Reliability and Interrater Agreement. Organ. Res. Methods 11, 815-852. doi:10.1177/1094428106296642

Lee, L., Wong, P.K., Foo, M. Der, Leung, A., 2011. Entrepreneurial intentions: The influence of organizational and individual factors. J. Bus. Ventur. 26, 124-136. doi:10.1016/j.jbusvent.2009.04.003

Lewin, K., 1936. Principles of Topological Psychology. McGraw-Hill, New York.

Lüdtke, O., Trautwein, U., Kunter, M., Baumert, J., 2006. Reliability and agreement of student ratings of the classroom environment: A reanalysis of TIMSS data. Learn. Environ. Res. 9, 215-230. doi:10.1007/s10984-006-9014-8

Lumpkin, G.T., Dess, G.G., 1996. Clarifying the entrepreneurial orientation construct and linking it to performance. Acad. Manag. Rev. 21, 135-172. doi:10.5465/AMR.1996.9602161568

Lüthje, C., Franke, N., 2004. Entrepreneurial Intentions of Business Students: A Benchmarking Study. Int. J. Innov. Technol. Manag. 1, 269-288.

Maas, C.J., Hox, J.J., 2005. Sufficient Sample Sizes for Multilevel Modeling. Methodology 1, 86-92. doi:10.1027/1614-1881.1.3.86 
Maitlis, S., 2005. The Social Processes of Organizational Sensemaking. Acad. Manag. J. 48, 21-49.

Martin, B.C., McNally, J.J., Kay, M.J., 2013. Examining the formation of human capital in entrepreneurship: A meta-analysis of entrepreneurship education outcomes. J. Bus. Ventur. 28, 211-224. doi:10.1016/j.jbusvent.2012.03.002

Mellahi, K., Harris, L.C., 2016. Response Rates in Business and Management Research: An Overview of Current Practice and Suggestions for Future Direction. Br. J. Manag. 27, 426-437. doi:10.1111/1467-8551.12154

Mirchandani, K., 1999. Feminist insight on gendered work: new directions in research on women and entrepreneurship. Gender, Work Organ. 6, 224-235.

Mok, K.H., 2005. Fostering entrepreneurship: Changing role of government and higher education governance in Hong Kong. Res. Policy 34, 537-554. doi:10.1016/j.respol.2005.03.003

Muller-Camen, M., Salzgeber, S., 2005. Changes in Academic Work and the Chair Regime: The Case of German Business Administration Academics. Organ. Stud. 26, 271-290. doi:10.1177/0170840605049802

Neubaum, D.O., Mitchell, M.S., Schminke, M., 2004. Firm Newness , Entrepreneurial and Ethical Climate. J. Bus. Ethics 52, 335-347. doi:10.1007/s10551-004-1532-7

Nezlek, J.B., 2011. Multilevel Modelling for Social and Personality Psychology. Sage, London.

Nisbett, R.E., Wilson, T.D., 1977. The halo effect: Evidence for unconscious alteration of judgments. J. Pers. Soc. Psychol. 35, 250-256. doi:http://dx.doi.org.ezproxy.snhu.edu/10.1037/00223514.35.4.250

Niskanen, T., 1994. Safety climate in the road administration. Saf. Sci. 17, 237-255.

O’Shea, R.P., Allen, T.J., Chevalier, A., Roche, F., 2005. Entrepreneurial orientation, technology transfer and spinoff performance of U.S. universities. Res. Policy 34, 994-1009. doi:10.1016/j.respol.2005.05.011

Parker, C.P., Baltes, B.B., Young, S. a., Huff, J.W., Altmann, R. a., LaCost, H. a., Roberts, J.E., 2003. Relationships between psychological climate perceptions and work outcomes: A meta-analytic review. J. Organ. Behav. 24, 389-416. doi:10.1002/job.198

Patterson, M.G., West, M., Shackleton, V.J., Dawson, J.F., Lawthom, R., Maitlis, S., Robinson, D.L., Wallace, A.M., 2005. Validating the organizational climate measure: links to managerial practices, productivity and innovation. J. Organ. Behav. 26, 379-408. doi:10.1002/job.312

Payne, R.L., Pugh, S.S., 1976. Organizational structure and organization climate, in: Dunnette, M.D. (Ed.), Handbook of Industrial and Organizational Psychology. Rand McNally, Chicago.

Pfeifer, C.M., Schneider, B., 1974. University climate perceptions by black and white students. J. Appl. Psychol. 59, 660-662. doi:10.1037/h0037300

Pittaway, L., Cope, J., 2007. Entrepreneurship Education: A Systematic Review of the Evidence. Int. Small Bus. J. 25, 479-510. doi:10.1177/0266242607080656

Porter, S.R., Whitcomb, M.E., 2003. The Impact of Lottery Incentives on Student Survey Response Rates. Res. High. Educ. 44, 389-407.

Rabe-Hesketh, S., Skrondal, A., 2008. Multilevel and Longitudinal Modeling using Stata, 2nd ed. Stata Press, College Station, TX.

Rasmussen, E., Borch, O.J., 2010. University capabilities in facilitating entrepreneurship: A longitudinal study of spin-off ventures at mid-range universities. Res. Policy 39, 602-612. doi:10.1016/j.respol.2010.02.002

Raudenbush, S.W., Bryk, A., 2002. Hierarchical Linear Models: Applications and Data Analyses Methods, 2nd ed. Sage Publications, Newbury Park, CA.

Rentsch, J.R., 1990. Climate and culture: Interaction and qualitative differences in organizational meanings. J. Appl. Psychol. 75, 668-681. doi:10.1037//0021-9010.75.6.668

Riordan, C.M., Vandenberg, R.J., Richardson, H.A., 2005. Employee involvement climate and organizational effectiveness. Hum. Resour. Manage. 44, 471-488. doi:10.1002/hrm.20085

Robinson, W., 1950. Ecological Correlations and Behaviour of Individuals. Am. Sociol. Rev. 15, 351357.

Ruef, M., Aldrich, H.E., Carter, N.M., 2003. The structure of founding teams: Homophily, strong ties, 
and isolation among US entrepreneurs. Am. Sociol. Rev. 68, 195-222. doi:10.2307/1519766

Schein, E.H., 2000. Sense and nonsense about culture and climate, in: Ashkanasy, N.M., Wilderom, C.P.M., Peterson, M. (Eds.), Handbook of Organizational Culture and Climate. Sage, Thousand Oaks, CA.

Schein, E.H., 1990. Organizational Culture. Am. Psychol. 45, 109-119. doi:10.1037//0003066X.45.2.109

Scherer, R.F., Adams, J.S., Carley, S.S., Wiebe, F.A., 1989. Role Model Performance Effects on Development of Entrepreneurial Career Preference. Entrep. Theory Pract. 13, 53-71.

Schmude, J., Welter, F., Heumann, S., 2008. Entrepreneurship Research in Germany. Entrep. Theory Pract. 32, 289-311. doi:10.1111/j.1540-6520.2007.00227.x.

Schneider, B., 1990. The climate for service: An application of the climate construct, in: Schneider, B. (Ed.), Organizational Climate and Culture. Jossey-Bass, San Francisco, pp. 383-412.

Schneider, B., 1983. Work climates: An interactionist perspective, in: Feimer, N.R., Geller, E.S. (Eds.), Environmental Psychology: Directions and Perspectives. Praeger, New York.

Schneider, B., Ehrhart, M.G., Macey, W.H., 2013. Organizational climate and culture. Annu. Rev. Psychol. 64, 361-88. doi:10.1146/annurev-psych-113011-143809

Schneider, B., González-Romá, V., Ostroff, C., West, M.A., 2017. Organizational climate and culture: Reflections on the history of the constructs in the Journal of Applied Psychology. J. Appl. Psychol. 102, 468-482. doi:10.1037/ap10000090

Schneider, B., Reichers, A.E., 1983. On the Etiology of Climates. Pers. Psychol. 36, 19-39.

Schneider, B., Salvaggio, A.N., Subirats, M., 2002. Climate strength: a new direction for climate research. J. Appl. Psychol. 87, 220-229. doi:10.1037//0021-9010.87.2.220

Schneider, B., White, S.S., Paul, M.C., 1998. Linking service climate and customer perceptions of service quality: test of a causal model. J. Appl. Psychol. 83, 150-163.

Shepherd, D.A., Patzelt, H., Haynie, J.M., 2010. Entrepreneurial Spirals: Deviation-Amplifying Loops of an Entrepreneurial Mindset and Organizational Culture. Entrep. Theory Pract. 34, 59-82. doi:10.1111/j.1540-6520.2009.00313.x

Siegel, D.S., Wright, M., 2015. Academic Entrepreneurship: Time for a Rethink? Br. J. Manag. 26, 582-595. doi:10.1111/1467-8551.12116

Sieger, P., Monsen, E., 2015. Founder, Academic, or Employee? A Nuanced Study of Career Choice Intentions. J. Small Bus. Manag. 53, 30-57. doi:10.1111/jsbm.12181

Silver, H., 2003. Does a University Have a Culture? Stud. High. Educ. 28, 157-169. doi:10.1080/0307507032000058118

Sine, W.D., Shane, S., Gregorio, D. Di, 2003. The Halo Effect and Technology Licensing: The Influence of Institutional Prestige on the Licensing of University Inventions. Manage. Sci. 49, 478-496. doi:10.1287/mnsc.49.4.478.14416

Snijders, T., Bosker, R., 2004. Multilevel Analysis: An Introduction to Basic and Advanced Multilevel Modeling, 5th ed. Sage, London et al.

Thapa, A., Cohen, J., Guffey, S., Higgins-D'Alessandro, A., 2013. A Review of School Climate Research. Rev. Educ. Res. 83, 357-385. doi:10.3102/0034654313483907

U.S. Department of Commerce, 2013. The innovative and entrepreneurial university.

Van Looy, B., Landoni, P., Callaert, J., van Pottelsberghe, B., Sapsalis, E., Debackere, K., 2011. Entrepreneurial effectiveness of European universities: An empirical assessment of antecedents and trade-offs. Res. Policy 40, 553-564. doi:10.1016/j.respol.2011.02.001

von Graevenitz, G., Harhoff, D., Weber, R., 2010. The effects of entrepreneurship education. J. Econ. Behav. Organ. 76, 90-112. doi:10.1016/j.jebo.2010.02.015

Walter, S.G., Parboteeah, K.P., Walter, A., 2013. University departments and self-employment intentions of business students: A cross-level analysis. Entrep. Theory Pract. 37, 175-200. doi:10.1111/j.1540-6520.2011.00460.x

Walumbwa, F.O., Wu, C., Orwa, B., 2008. Contingent reward transactional leadership, work attitudes, and organizational citizenship behavior: The role of procedural justice climate perceptions and strength. Leadersh. Q. 19, 251-265. doi:10.1016/j.leaqua.2008.03.004 
Weick, K.E., 1995. Sensemaking in Organizations. Sage, Thousand Oaks, London, New Dehli.

Wu, T., Chen, C., Li, C., 2008. A correlation among safety leadership, safety climate and safety performance. J. Loss Prev. Process Ind. 21, 307-318. doi:10.1016/j.jlp.2007.11.001

Wu, T., Liu, C., Lu, M., 2007. Safety climate in university and college laboratories: Impact of organizational and individual factors. J. Safety Res. 38, 91-102. doi:10.1016/j.jsr.2007.01.003

Zagenczyk, T.J., Purvis, R.L., 2015. Multiplex Social Network Ties and Psychological Climate, in: Academy of Management 2015 Annual Meeting. Vancouver, BC.

Zellweger, T., Sieger, P., Halter, F., 2011. Should I stay or should I go? Career choice intentions of students with family business background. J. Bus. Ventur. 26, 521-536. doi:10.1016/j.jbusvent.2010.04.001

Zohar, D., Luria, G., 2005. A multilevel model of safety climate: cross-level relationships between organization and group-level climates. J. Appl. Psychol. 90, 616-28. doi:10.1037/00219010.90.4.616 
Table 1: Independent variables

\begin{tabular}{|c|c|c|}
\hline & Description and measurement & Data Source \\
\hline \multicolumn{3}{|l|}{ Variables on the context level: } \\
\hline $\mathrm{C}_{1}$ : Regional population density & $\begin{array}{l}\text { Regional population density (in } 1000 \text { people } \\
\text { per square kilometer) in spatial planning re- } \\
\text { gions ('Raumordnungsregionen') } 2011 \text {; }\end{array}$ & $\begin{array}{l}\text { German Federal Sta- } \\
\text { tistical Office }\end{array}$ \\
\hline $\mathrm{C}_{2}$ : University of applied sciences & Binary $(1=$ yes $)$ & $\begin{array}{l}\text { German Federal Sta- } \\
\text { tistical Office }\end{array}$ \\
\hline $\mathrm{C}_{3}: \#$ students (in 1000) & $\begin{array}{l}\text { Absolute number of students at university } \\
\text { (in } 1000 \text { students) in } 2013\end{array}$ & $\begin{array}{l}\text { German Federal Sta- } \\
\text { tistical Office }\end{array}$ \\
\hline $\mathrm{C}_{4}:$ General reputation & $\begin{array}{l}\text { Share of students who indicated that the } \\
\text { main reason for studying at their respective } \\
\text { university was its "strong reputation in gen- } \\
\text { eral" }\end{array}$ & Student survey (2014) \\
\hline $\begin{array}{l}\mathrm{C}_{5} \text { : University's entrepr. budget (share } \\
\text { of total budget) }\end{array}$ & $\begin{array}{l}\text { Share of the total budget that the university } \\
\text { spent for the support of entrepreneurship in } \\
\text { the financial year } 2012 \text {. }\end{array}$ & $\begin{array}{l}\text { University survey } \\
\text { (2013) }\end{array}$ \\
\hline $\begin{array}{l}\mathrm{C}_{6}: \text { Chair of entrepreneurship at uni- } \\
\text { versity }\end{array}$ & Binary $(1=$ yes $)$ & $\begin{array}{l}\text { University survey } \\
(2013)\end{array}$ \\
\hline $\begin{array}{l}\mathrm{C}_{7} \text { : Share of faculties with entrepr. of- } \\
\text { ficer }\end{array}$ & $\begin{array}{l}\text { Share of faculties with an entrepreneurship } \\
\text { officer in } 2013\end{array}$ & $\begin{array}{l}\text { University survey } \\
(2013)\end{array}$ \\
\hline $\mathrm{C}_{8}: \#$ entrepr. competitions & $\begin{array}{l}\text { Absolute number of entrepreneurship, busi- } \\
\text { ness plan and idea competitions at univer- } \\
\text { sity in academic year } 2012 / 13\end{array}$ & $\begin{array}{l}\text { University survey } \\
\text { (2013) }\end{array}$ \\
\hline $\mathrm{C}_{9}$ : Elective entrepr. course attendance & $\begin{array}{l}\text { Share of students who have attended at least } \\
\text { one entrepreneurship course as elective. }\end{array}$ & Student survey (2014) \\
\hline $\begin{array}{l}\mathrm{C}_{10} \text { : Compulsory entrepr. course atten- } \\
\text { dance }\end{array}$ & $\begin{array}{l}\text { Share of students who have attended at least } \\
\text { one ent. course as regular part of their studies. }\end{array}$ & Student survey (2014) \\
\hline $\begin{array}{l}\mathrm{C}_{11} \text { : Elective entrepr. course attend- } \\
\text { ance (share of male students) }\end{array}$ & $\begin{array}{l}\text { Share of male students who have attended at } \\
\text { least one ent. course as elective. }\end{array}$ & Student survey (2014) \\
\hline $\begin{array}{l}\mathrm{C}_{12} \text { : Compulsory entrepr. course at- } \\
\text { tendance (share of male students) }\end{array}$ & $\begin{array}{l}\text { Share of male students who have attended at } \\
\text { least one ent. course as regular part of their } \\
\text { studies. }\end{array}$ & Student survey (2014) \\
\hline \multicolumn{3}{|l|}{ Variables on the individual level: } \\
\hline $\mathrm{X}_{1}$ : Gender & Binary $(1=$ male $)$ & Student survey (2014) \\
\hline $\mathrm{X}_{2}$ : Parental self-employment & $\begin{array}{l}\text { Binary ( } 1 \text { if father or mother or both are } \\
\text { currently self-employed) }\end{array}$ & Student survey (2014) \\
\hline $\mathrm{X}_{3}:$ Academic Status & $\begin{array}{l}\text { Binary }(1=\text { studies on master level, } 0= \\
\text { bachelor level })\end{array}$ & Student survey (2014) \\
\hline $\mathrm{X}_{4}$ : Elective entrepr. course & $\begin{array}{l}\text { Student has attended at least one entrepre- } \\
\text { neurship course as elective. }\end{array}$ & Student survey (2014) \\
\hline $\mathrm{X}_{5}$ : Compulsory entrepr. course & $\begin{array}{l}\text { Student has attended at least one ent.course } \\
\text { as regular part of his/her studies. }\end{array}$ & Student survey (2014) \\
\hline $\begin{array}{l}\mathrm{X}_{6} \text { : Reason for university choice: } \\
\quad \text { strong reputation }\end{array}$ & $\begin{array}{l}\text { Binary ( } 1 \text { if student has indicated that the } \\
\text { most important reason why he/she has cho- } \\
\text { sen to study at this university was its } \\
\text { "Strong reputation in general") }\end{array}$ & Student survey (2014) \\
\hline $\begin{array}{l}\mathrm{X}_{7}: \text { Subject of study (different binary } \\
\text { variables) }\end{array}$ & $\begin{array}{l}\text { Binary (1=yes) for each subject group; clas- } \\
\text { sification according to official statistics }\end{array}$ & Student survey (2014) \\
\hline
\end{tabular}




\section{Table 2: Summary statistics and correlations of all variables}

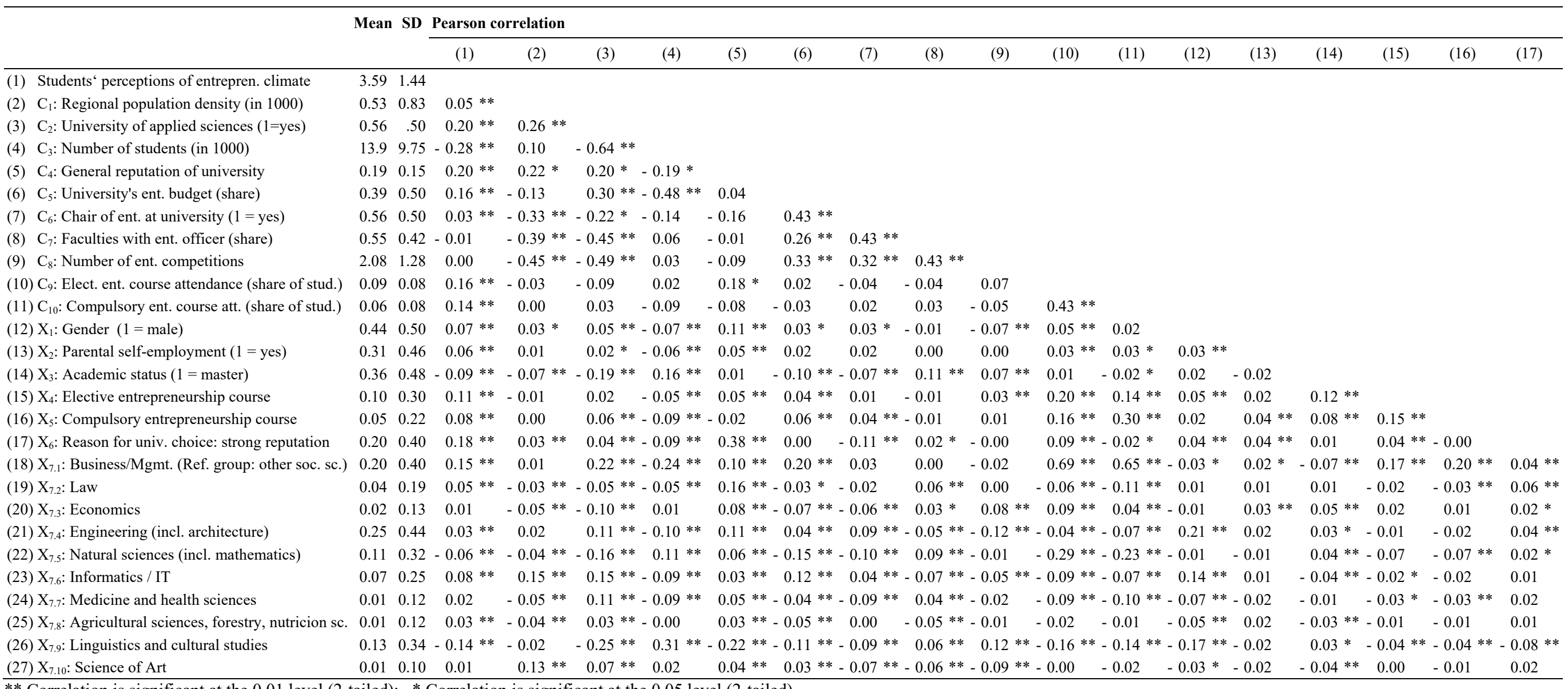

** Correlation is significant at the 0.01 level (2-tailed); * Correlation is significant at the 0.05 level (2-tailed)

The analysis is based on data from 8009 students; own calculation based on data from GUESSS 
Table 3: Linear multilevel regression models on students' perceptions of the entrepreneurial climate

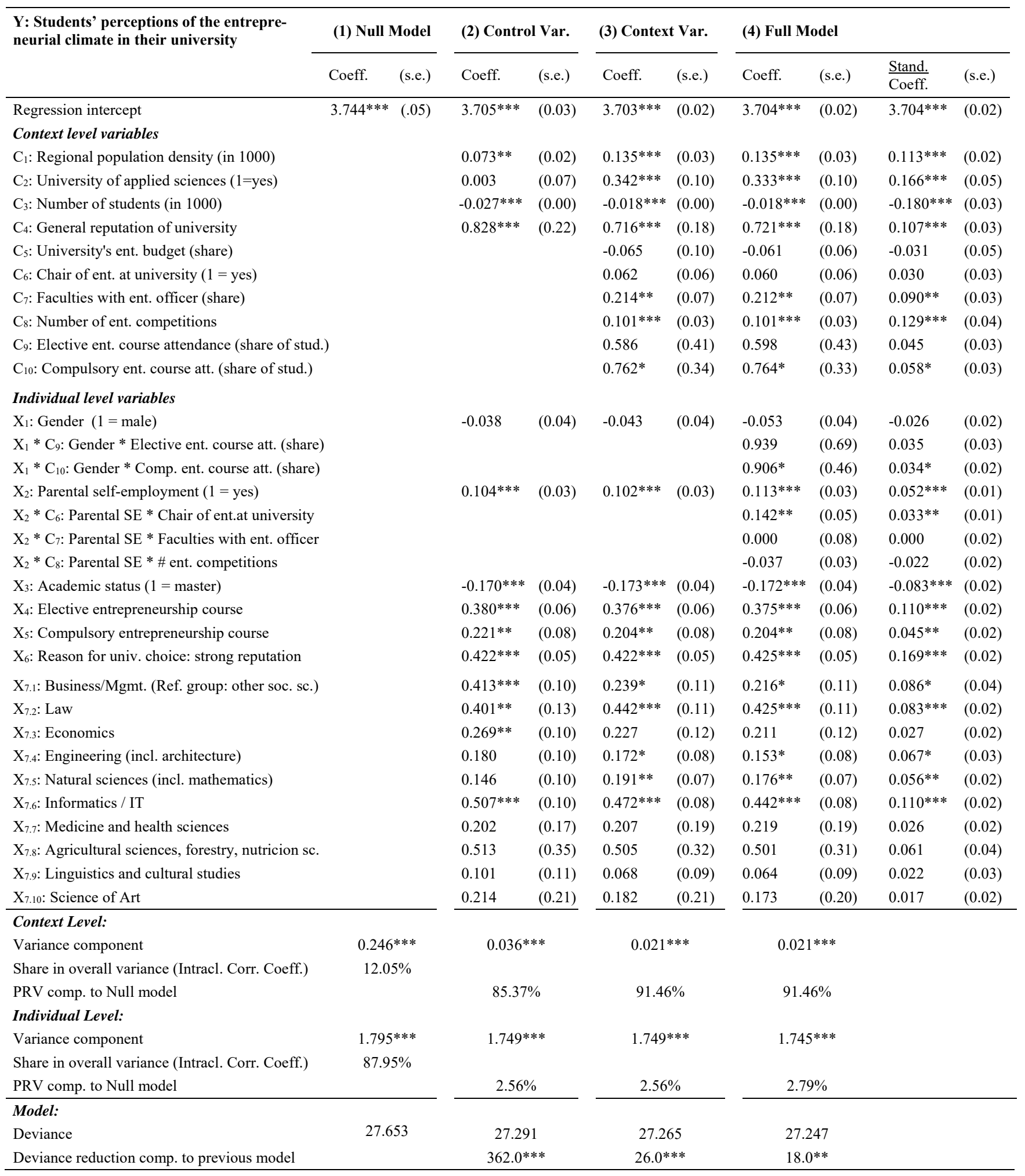

The table displays unstandardized regression coefficients (if not reported otherwise) and corresponding standard errors. All predictor variables are grand mean centered. PRV: Proportion Reduction in Variance. Influence is significant on the $0.001(* * *)$, the $0.01(* *)$, or the $0.05(*)$ level respectively. The analyses are based on data from 8,009 individuals from 120 subject groups at 22 universities. Sources: Own calculations based on data from GUESSS. 
Figure 1: Interaction plot of parental self-employment and existence of a Chair of entrepreneurship on ent. climate perceptions

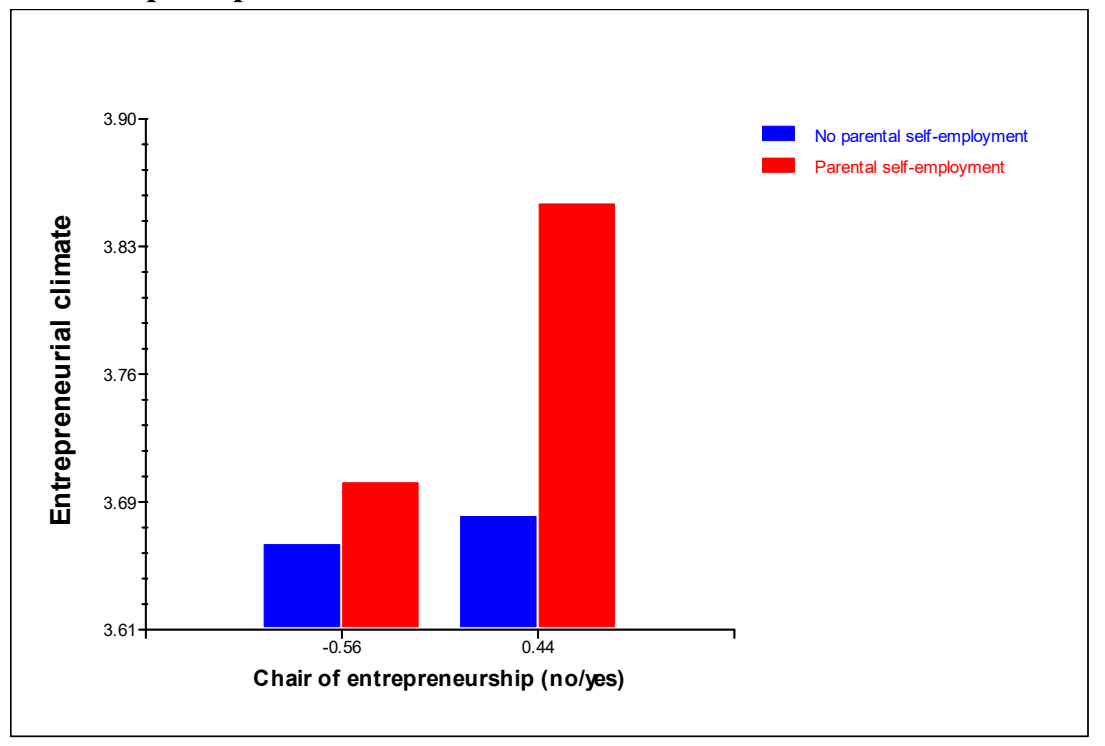

Figure 2: Interaction plot of gender and share of students who have participated in a compulsory entrepreneurship course on ent. climate perceptions

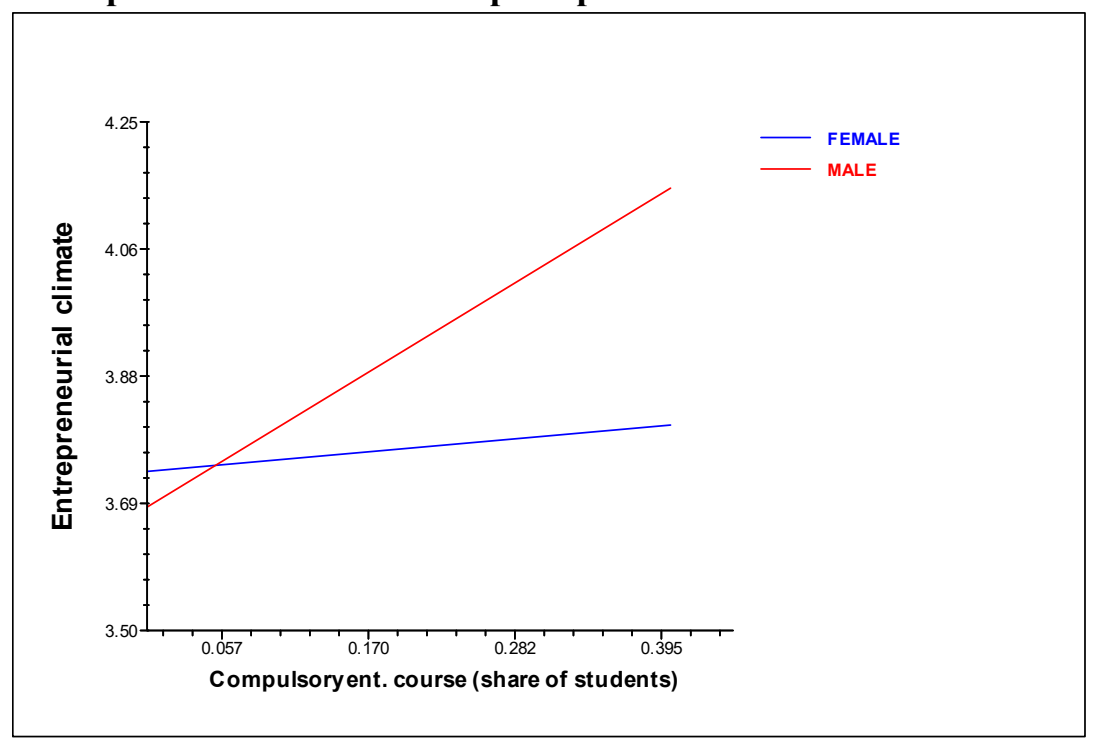


Figure 3: Interaction plot of gender and share of male students who have participated in a compulsory entrepreneurship course on ent. climate perceptions

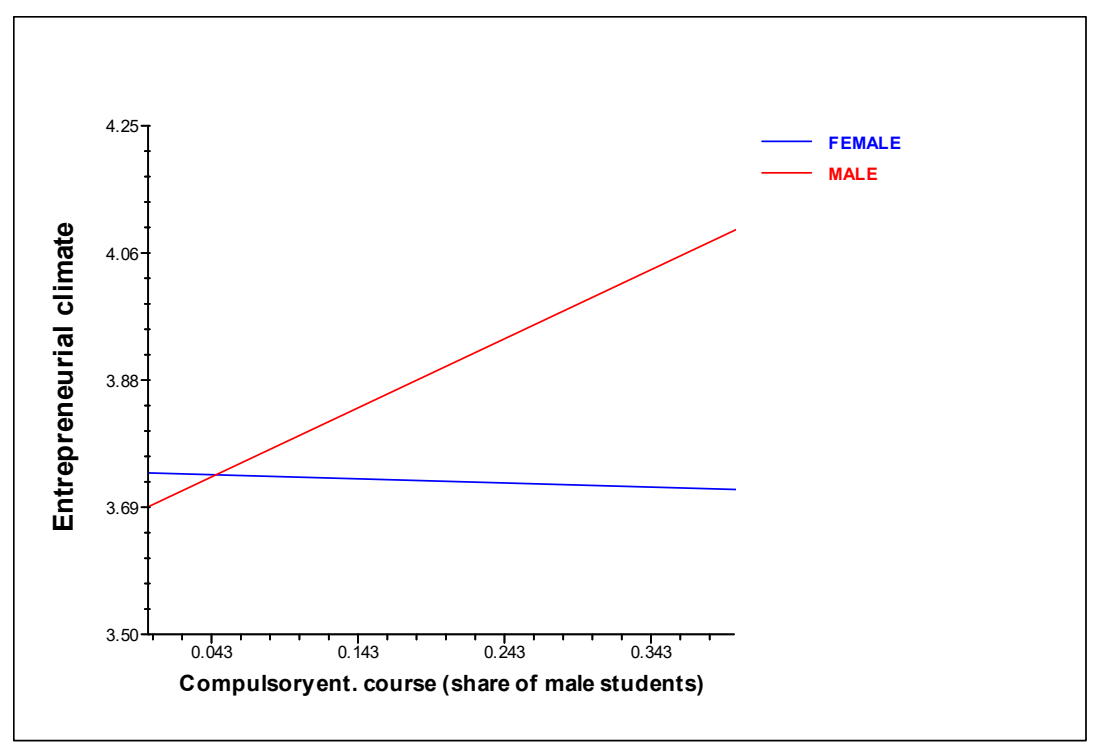

Figure 4: The entrepreneurial climate at selected German universities 2013 and 2016

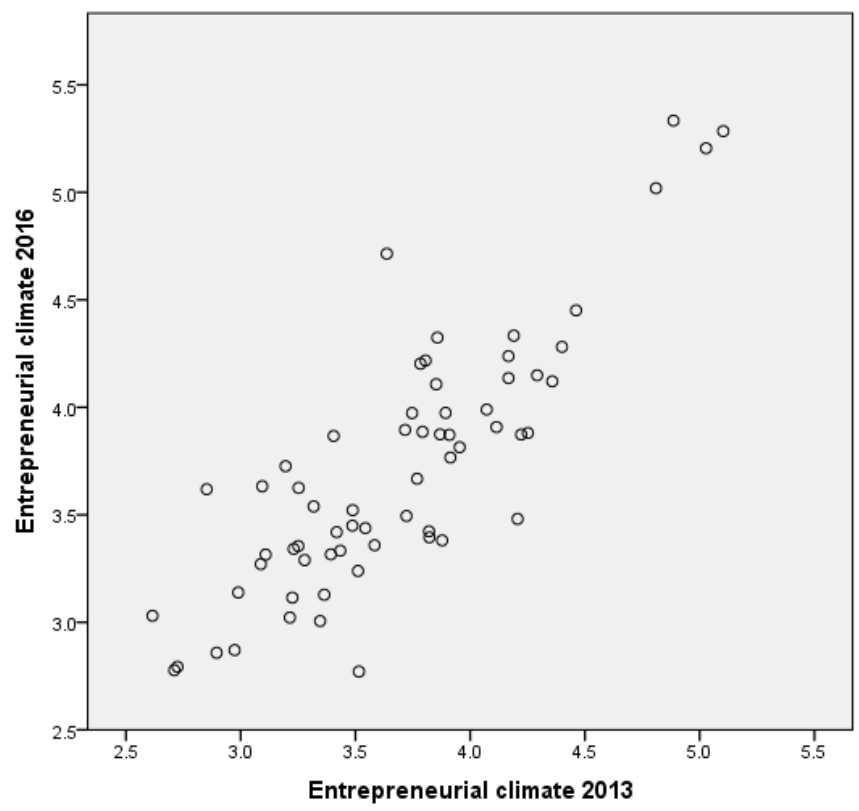

Note: $\mathrm{n}=64$ entrepreneurial climate values of university subject groups $\left(\mathrm{r}=.844^{* *}\right)$ 
Table 4: Linear multilevel regression models on students' perceptions of the entrepreneurial climate (Alternative Models)

\begin{tabular}{|c|c|c|c|c|c|c|c|c|c|c|}
\hline \multirow[t]{2}{*}{$\begin{array}{l}\text { Y: Students' perceptions of the entrepreneurial } \\
\text { climate in their university }\end{array}$} & \multicolumn{2}{|c|}{$\begin{array}{l}\text { (4) Full Model } \\
\text { (as in Table 3) }\end{array}$} & \multicolumn{2}{|c|}{$\begin{array}{l}\text { Alt. Model } 1 \\
\text { (male course att.) }\end{array}$} & \multicolumn{2}{|c|}{$\begin{array}{l}\text { Alt. Model } 2 \\
(\mathrm{n}>=20)\end{array}$} & \multicolumn{2}{|c|}{$\begin{array}{l}\text { Alt. Model } 3 \\
\text { (excl. Mittweida } \\
\text { \& Munich) }\end{array}$} & \multicolumn{2}{|c|}{$\begin{array}{l}\text { Alt. Model } 4 \\
\text { (only students w. } \\
\text { affinity for ent.) }\end{array}$} \\
\hline & Coeff. & (s.e.) & Coeff. & (s.e.) & Coeff. & (s.e.) & Coeff. & (s.e.) & Coeff. & (s.e.) \\
\hline Regression intercept & $3.704 * * *$ & $(0.02)$ & $3.710 * * *$ & $(0.03)$ & $3.672 * * *$ & $(0.02)$ & $3.694 * * *$ & $(0.03)$ & $3.914 * * *$ & $(0.04)$ \\
\hline \multicolumn{11}{|l|}{ Context level variables } \\
\hline $\mathrm{C}_{1}$ : Regional population density (in 1000 ) & $0.136^{* * *}$ & $(0.03)$ & $0.127 * * *$ & $(0.02)$ & $0.132 * * *$ & $(0.03)$ & $0.133 * * *$ & $(0.03)$ & $0.159 * * *$ & $(0.03)$ \\
\hline $\mathrm{C}_{2}$ : University of applied sciences ( $1=$ yes) & $0.333 * * *$ & $(0.10)$ & $0.303^{* *}$ & $(0.10)$ & $0.306^{* *}$ & $(0.10)$ & $0.374 * * *$ & $(0.10)$ & $0.406^{* *}$ & $(0.14)$ \\
\hline $\mathrm{C}_{3}$ : Number of students (in 1000) & $-0.018 * * *$ & $(0.00)$ & $-0.019 * * *$ & $(0.00)$ & $-0.018 * * *$ & $(0.00)$ & $-0.019 * * *$ & $(0.00)$ & $-0.019 * * *$ & $(0.00)$ \\
\hline $\mathrm{C}_{4}$ : General reputation of university & $0.721 * * *$ & $(0.18)$ & $0.790 * * *$ & $(0.18)$ & $0.707 * * *$ & $(0.19)$ & $0.641 * * *$ & $(0.17)$ & 0.292 & $(0.24)$ \\
\hline $\mathrm{C}_{5}$ : University's ent. budget (share) & -0.061 & $(0.06)$ & -0.046 & $(0.11)$ & -0.041 & $(0.11)$ & -0.084 & $(0.10)$ & -0.156 & $(0.12)$ \\
\hline $\mathrm{C}_{6}$ : Chair of ent. at university $(1=$ yes $)$ & 0.060 & $(0.06)$ & 0.050 & $(0.06)$ & 0.058 & $(0.07)$ & 0.039 & $(0.06)$ & 0.077 & $(0.10)$ \\
\hline $\mathrm{C}_{7}$ : Faculties with ent. officer (share) & $0.211^{* *}$ & $(0.07)$ & $0.181^{*}$ & $(0.07)$ & $0.179 *$ & $(0.07)$ & $0.222 * *$ & $(0.07)$ & $0.266^{*}$ & $(0.11)$ \\
\hline $\mathrm{C}_{8}:$ Number of ent. competitions & $0.101 * * *$ & $(0.03)$ & $0.101 * * *$ & $(0.03)$ & $0.090 * *$ & $(0.03)$ & $0.112 * * *$ & $(0.03)$ & $0.135 * * *$ & $(0.04)$ \\
\hline $\mathrm{C}_{9}$ : Elective ent. course attendance (share of stud.) & 0.598 & $(0.43)$ & & & 0.857 & $(0.48)$ & 0.623 & $(0.42)$ & $1.224 *$ & $(0.57)$ \\
\hline $\mathrm{C}_{10}$ : Compulsory ent. course att. (share of stud.) & $0.764 *$ & $(0.33)$ & & & $0.832 *$ & $(0.39)$ & $0.706^{*}$ & $(0.30)$ & 0.570 & $(0.42)$ \\
\hline $\mathrm{C}_{11}$ : Elective ent. course att. (share of male stud.) & & & -0.149 & $(0.32)$ & & & & & & \\
\hline $\mathrm{C}_{12}$ : Comp. ent. course att. (share of male stud.) & & & 0.549 & $(0.31)$ & & & & & & \\
\hline \multicolumn{11}{|l|}{ Individual level variables } \\
\hline $\mathrm{X}_{1}$ : Gender $(1=$ male $)$ & -0.053 & $(0.04)$ & -0.050 & $(0.04)$ & -0.040 & $(0.04)$ & -0.042 & $(0.04)$ & -0.018 & $(0.07)$ \\
\hline $\mathrm{X}_{1} * \mathrm{C}_{9}$ : Gender $*$ Elect. ent. course att. (share) & 0.939 & $(0.69)$ & & & 0.838 & $(0.75)$ & 0.924 & $(0.71)$ & $1.418^{+}$ & $(0.73)$ \\
\hline $\mathrm{X}_{1} * \mathrm{C}_{10}:$ Gender $*$ Comp. ent. course att. (share) & $0.906^{*}$ & $(0.46)$ & & & $0.929 *$ & $(0.46)$ & $0.993 *$ & $(0.45)$ & 0.796 & $(0.62)$ \\
\hline \multicolumn{3}{|c|}{$\mathrm{X}_{1} * \mathrm{C}_{11}:$ Gndr $*$ Elect. ent. course att. (share males) } & 0.486 & $(0.50)$ & & & & & & \\
\hline \multicolumn{3}{|l|}{$\mathrm{X}_{1} * \mathrm{C}_{12}: \mathrm{Gndr} *$ Comp. ent. course att. (share males) } & $1.079 * *$ & $(0.41)$ & & & & & & \\
\hline $\mathrm{X}_{2}:$ Parental self-employment $(1=$ yes $)$ & $0.113 * * *$ & $(0.03)$ & $0.112 * * *$ & $(0.03)$ & $0.108 * * *$ & $(0.03)$ & $0.124 * * *$ & $(0.03)$ & 0.091 & $(0.06)$ \\
\hline $\mathrm{X}_{2} * \mathrm{C}_{6}:$ Parental SE $*$ Chair of ent.at university & $0.142 * *$ & $(0.05)$ & $0.143 * *$ & $(0.05)$ & $0.142 * *$ & $(0.05)$ & $0.134^{*}$ & $(0.05)$ & 0.015 & $(0.12)$ \\
\hline $\mathrm{X}_{2} * \mathrm{C}_{7}$ : Parental SE $*$ Faculties with ent. officer & 0.000 & $(0.08)$ & 0.000 & $(0.08)$ & 0.008 & $(0.08)$ & -0.010 & $(0.08)$ & -0.007 & $(0.16)$ \\
\hline $\mathrm{X}_{2} * \mathrm{C}_{8}:$ Parental SE $*$ \# ent. competitions & -0.037 & $(0.03)$ & -0.037 & $(0.03)$ & -0.038 & $(0.03)$ & -0.035 & $(0.03)$ & -0.002 & $(0.04)$ \\
\hline $\mathrm{X}_{3}:$ Academic status $(1=$ master $)$ & $-0.172 * * *$ & $(0.04)$ & $-0.171 * * *$ & $(0.04)$ & $-0.170 * * *$ & $(0.04)$ & $-0.162 * * *$ & $(0.04)$ & -0.064 & $(0.07)$ \\
\hline $\mathrm{X}_{4}$ : Elective entrepreneurship course & $0.375^{* * *}$ & $(0.06)$ & $0.390 * * *$ & $(0.06)$ & $0.372 * * *$ & $(0.06)$ & $0.383 * * *$ & $(0.06)$ & $0.232 * * *$ & $(0.07)$ \\
\hline $\mathrm{X}_{5}$ : Compulsory entrepreneurship course & $0.204^{* *}$ & $(0.08)$ & $0.218^{* *}$ & $(0.08)$ & $0.208 * *$ & $(0.08)$ & $0.197 * *$ & $(0.08)$ & 0.097 & $(0.09)$ \\
\hline $\mathrm{X}_{6}$ : Reason for univ. choice: strong reputation & $0.425 * * *$ & $(0.05)$ & $0.423 * * *$ & $(0.05)$ & $0.438 * * *$ & $(0.05)$ & $0.430 * * *$ & $(0.05)$ & $0.496^{* * *}$ & $(0.07)$ \\
\hline $\mathrm{X}_{7.1}$ : Business/Mgmt. (Ref. group: other soc. sc.) & $0.216^{*}$ & $(0.11)$ & $0.332 * *$ & $(0.11)$ & 0.129 & $(0.12)$ & $0.210^{*}$ & $(0.11)$ & 0.079 & $(0.14)$ \\
\hline $\mathrm{X}_{7.2: \text { Law }}$ & $0.425 * * *$ & $(0.11)$ & $0.425 * * *$ & $(0.12)$ & $0.350 * *$ & $(0.13)$ & $0.435^{* * *}$ & $(0.11)$ & 0.429 & $(0.28)$ \\
\hline $\mathrm{X}_{7.3}$ : Economics & 0.211 & $(0.12)$ & 0.248 & $(0.13)$ & 0.175 & $(0.12)$ & 0.217 & $(0.12)$ & 0.198 & $(0.18)$ \\
\hline $\mathrm{X}_{7.4}$ : Engineering (incl. architecture) & $0.153 *$ & $(0.08)$ & $0.166^{*}$ & $(0.08)$ & 0.096 & $(0.07)$ & $0.174 *$ & $(0.08)$ & 0.100 & $(0.13)$ \\
\hline $\mathrm{X}_{7.5}$ : Natural sciences (incl. mathematics) & $0.176^{* *}$ & $(0.07)$ & 0.149 & $(0.08)$ & 0.117 & $(0.07)$ & $0.174^{*}$ & $(0.08)$ & 0.269 & $(0.14)$ \\
\hline $\mathrm{X}_{7.6:}$ Informatics / IT & $0.442 * * *$ & $(0.08)$ & $0.442 * * *$ & $(0.09)$ & $0.311 * * *$ & $(0.08)$ & $0.448 * * *$ & $(0.08)$ & $0.364^{* *}$ & $(0.14)$ \\
\hline $\mathrm{X}_{7.7}:$ Medicine and health sciences & 0.219 & $(0.19)$ & 0.190 & $(0.18)$ & 0.188 & $(0.18)$ & 0.122 & $(0.24)$ & $0.464 *$ & $(0.24)$ \\
\hline $\mathrm{X}_{7.8}$ : Agricultural sciences, forestry, nutricion sc. & 0.501 & $(0.31)$ & 0.483 & $(0.32)$ & 0.422 & $(0.30)$ & 0.759 & $(0.43)$ & $0.915 * * *$ & $(0.24)$ \\
\hline $\mathrm{X}_{7.9}:$ Linguistics and cultural studies & 0.064 & $(0.09)$ & 0.075 & $(0.10)$ & 0.026 & $(0.09)$ & 0.062 & $(0.09)$ & 0.072 & $(0.16)$ \\
\hline $\mathrm{X}_{7.10}:$ Science of Art & 0.173 & $(0.20)$ & 0.127 & $(0.19)$ & -0.160 & $(0.20)$ & 0.179 & $(0.21)$ & $0.347 * *$ & $(0.13)$ \\
\hline Number of Level-1 Units & \multicolumn{2}{|c|}{8.009} & \multicolumn{2}{|c|}{8.009} & \multicolumn{2}{|c|}{7.750} & \multicolumn{2}{|c|}{7.569} & \multicolumn{2}{|c|}{2.404} \\
\hline Number of Level-2 Units & \multicolumn{2}{|c|}{120} & \multicolumn{2}{|c|}{120} & \multicolumn{2}{|c|}{100} & \multicolumn{2}{|c|}{109} & \multicolumn{2}{|c|}{120} \\
\hline \multicolumn{11}{|l|}{ Model: } \\
\hline Deviance of the Null Model & 27.65 & & 27.65 & & 26.7 & & 26.7 & & 8.74 & \\
\hline Deviance of the Full Model & $27.247^{*}$ & $* * *$ & 27.251 & $* * *$ & 26.378 & $* * *$ & 25.700 & $* * *$ & $8.376^{*}$ & $* *$ \\
\hline
\end{tabular}

The table displays unstandardized regression coefficients and corresponding standard errors. All predictor variables are grand mean centered.

Influence is significant on the $0.001(* * *)$, the $0.01\left(^{* *}\right)$, or the $0.05(*)$ level respectively. In alt. model 4 , the ${ }^{+}$indicates a significance on the 0.052 level.

Sources: Own calculations based on data from GUESSS. 
Table 5: Linear multilevel regression models on students' perceptions of the entrepreneurial climate (Only context level controls)

\begin{tabular}{|c|c|c|c|c|c|c|c|c|c|}
\hline \multirow[t]{2}{*}{$\begin{array}{l}\text { Y: Students' perceptions of the entrepreneurial } \\
\text { climate in their university }\end{array}$} & \multirow[t]{2}{*}{ (1) Null Model } & \multicolumn{2}{|l|}{$\mathbf{C}_{4}$} & \multicolumn{2}{|l|}{$\mathrm{C}_{4}, \mathrm{C}_{3}$} & \multicolumn{2}{|l|}{$\mathrm{C}_{4}, \mathrm{C}_{3}, \mathrm{C}_{2}$} & \multicolumn{2}{|c|}{$\mathrm{C}_{4}, \mathrm{C}_{3}, \mathrm{C}_{2}, \mathrm{C}_{1}$} \\
\hline & & Coeff. & (s.e.) & Coeff. & (s.e.) & Coeff. & (s.e.) & Coeff. & (s.e.) \\
\hline $\mathrm{C}_{1}$ : Regional population density (in 1000) & & & & & & & & $0.073 * *$ & $(0.02)$ \\
\hline $\mathrm{C}_{2}$ : University of applied sciences ( $1=$ yes) & & & & & & 0.067 & $(0.06)$ & 0.003 & $(0.07)$ \\
\hline $\mathrm{C}_{3}:$ Number of students (in 1000) & & & & $-0.026^{* * *}$ & $(0.00)$ & $-0.024 * * *$ & $(0.00)$ & $-0.027 * * *$ & $(0.00)$ \\
\hline $\mathrm{C}_{4}$ : General reputation of university & & $1.281 * * *$ & $(0.30)$ & $0.910 * * *$ & $(0.23)$ & $0.904 * * *$ & $(0.22)$ & $0.828 * * *$ & $(0.22)$ \\
\hline \multicolumn{10}{|l|}{ Context Level: } \\
\hline Variance Component & $0.246^{* * *}$ & \multicolumn{2}{|c|}{$0.103 * * *$} & \multicolumn{2}{|c|}{$0.040 * * *$} & \multicolumn{2}{|c|}{$0.039 * * *$} & \multicolumn{2}{|c|}{$0.036^{* * *}$} \\
\hline $\begin{array}{l}\text { Proportion reduction in variance comp. to Null } \\
\text { model }\end{array}$ & & \multicolumn{2}{|c|}{$58.13 \%$} & \multicolumn{2}{|c|}{$83.74 \%$} & \multicolumn{2}{|c|}{$84.15 \%$} & \multicolumn{2}{|c|}{$85.37 \%$} \\
\hline
\end{tabular}

The table displays unstandardized logit coefficients and corresponding standard errors. All predictor variables are grand mean centered.

Except from the Null Modell, all models were calculated including the same individual level variables as in Model (2) in Table 3.

Influence is significant on the $0.001(* * *)$, the $0.01(* *)$, or the $0.05(*)$ level respectively.

The analyses are based on data from 8,009 individuals from 120 subject groups 22 universities. Sources: Own calculations based on data from GUESSS. 